\title{
In situ measurements of cloud microphysics and aerosol over coastal Antarctica during the MAC campaign
}

\author{
Sebastian J. O'Shea ${ }^{1}$, Thomas W. Choularton ${ }^{1}$, Michael Flynn ${ }^{1}$, Keith N. Bower ${ }^{1}$, Martin Gallagher ${ }^{1}$, \\ Jonathan Crosier $^{1,2}$, Paul Williams ${ }^{1,2}$, Ian Crawford ${ }^{1}$, Zoë L. Fleming ${ }^{3}$, Constantino Listowski ${ }^{4, a}$, \\ Amélie Kirchgaessner ${ }^{4}$, Russell S. Ladkin ${ }^{4}$, and Thomas Lachlan-Cope ${ }^{4}$ \\ ${ }^{1}$ School of Earth and Environmental Sciences, University of Manchester, Oxford Road, Manchester, UK \\ ${ }^{2}$ National Centre for Atmospheric Science, University of Manchester, Oxford Road, Manchester, UK \\ ${ }^{3}$ National Centre for Atmospheric Science, Department of Chemistry, University of Leicester, Leicester, UK \\ ${ }^{4}$ British Antarctic Survey, NERC, High Cross, Madingley Rd, Cambridge, UK \\ ${ }^{a}$ now at: LATMOS/IPSL, UVSQ Université Paris-Saclay, UPMC Univ. Paris 06, CNRS, Guyancourt, France
}

Correspondence to: Sebastian J. O’Shea (sebastian.oshea@manchester.ac.uk)

Received: 7 March 2017 - Discussion started: 21 April 2017

Revised: 15 September 2017 - Accepted: 18 September 2017 - Published: 6 November 2017

\begin{abstract}
During austral summer 2015, the Microphysics of Antarctic Clouds (MAC) field campaign collected unique and detailed airborne and ground-based in situ measurements of cloud and aerosol properties over coastal Antarctica and the Weddell Sea. This paper presents the first results from the experiment and discusses the key processes important in this region, which is critical to predicting future climate change.

The sampling was predominantly of stratus clouds, at temperatures between -20 and $0{ }^{\circ} \mathrm{C}$. These clouds were dominated by supercooled liquid water droplets, which had a median concentration of $113 \mathrm{~cm}^{-3}$ and an interquartile range of $86 \mathrm{~cm}^{-3}$. Both cloud liquid water content and effective radius increased closer to cloud top. The cloud droplet effective radius increased from $4 \pm 2 \mu \mathrm{m}$ near cloud base to $8 \pm 3 \mu \mathrm{m}$ near cloud top.

Cloud ice particle concentrations were highly variable with the ice tending to occur in small, isolated patches. Below approximately $1000 \mathrm{~m}$, glaciated cloud regions were more common at higher temperatures; however, the clouds were still predominantly liquid throughout. When ice was present at temperatures higher than $-10^{\circ} \mathrm{C}$, secondary ice production most likely through the Hallett-Mossop mechanism led to ice concentrations 1 to 3 orders of magnitude higher than the number predicted by commonly used primary ice nucleation parameterisations. The drivers of the ice crystal variability are investigated. No clear dependence on the droplet size distribution was found. The source of first ice in
\end{abstract}

the clouds remains uncertain but may include contributions from biogenic particles, blowing snow or other surface ice production mechanisms.

The concentration of large aerosols (diameters 0.5 to $1.6 \mu \mathrm{m})$ decreased with altitude and were depleted in air masses that originated over the Antarctic continent compared to those more heavily influenced by the Southern Ocean and sea ice regions. The dominant aerosol in the region was hygroscopic in nature, with the hygroscopicity parameter $\kappa$ having a median value for the campaign of 0.66 (interquartile range of 0.38). This is consistent with other remote marine locations that are dominated by sea salt/sulfate.

\section{Introduction}

Antarctic clouds have a central role in the weather and climate at high southern latitudes (Lubin et al., 1998; Lawson and Gettelman, 2014). Through snow precipitation and their radiative effects, they are key to the mass balance of the Antarctic ice sheet, which impacts global sea levels (van den Broeke et al., 2011) and Southern Ocean circulation (Bromwich et al., 2012). In addition, it has been suggested that changes in Antarctic clouds can influence weather patterns as far away as the tropics and even the extratropics of the Northern Hemisphere (Lubin et al., 1998). 
Despite their importance, Antarctic clouds are some of the least studied of any region around the globe (Bromwich et al., 2012). The remote location and harsh conditions cause significant logistical challenges for field projects in this region. As a consequence, there is evidence that clouds and their radiative properties are poorly represented in weather and climate models over Antarctica (Bromwich et al., 2013; King et al., 2015; Listowski and Lachlan-Cope, 2017) and the Southern Ocean (Bodas-Salcedo et al., 2012, 2016).

Key uncertainties concern the aerosol in the region, in particular the number and sources of cloud condensation nuclei (CCN) and ice nucleating particles (INPs). Conventional parameterisations predicting INP concentrations have primarily been developed using measurements at midlatitudes (e.g. Cooper, 1986; DeMott et al., 2010) and may not be appropriate for Antarctica. A number of intensive field campaigns have been conducted studying Arctic clouds (McFarquhar and Cober, 2004; McFarquhar et al., 2007; Verlinde et al., 2007; Lloyd et al., 2015a); however, analogies between the polar regions may also not be appropriate. The Arctic receives significant anthropogenic aerosol input due to its proximity to industrial nations and is therefore likely to have a significantly different type and number of CCN/INPs (Mauritsen et al., 2011; Lathem et al., 2013; Liu et al., 2015).

Previous multi-year measurements of aerosol at the Neumayer coastal Antarctic research station had a median condensation particle concentration of $258 \mathrm{~cm}^{-3}$. Minimum values (less than $100 \mathrm{~cm}^{-3}$ ) were typically observed in June/July, while concentrations increased in the austral summer to a maximum of approximately $1000 \mathrm{~cm}^{-3}$ in March (Weller et al., 2011). In winter, aerosol number and mass were both dominated by sea-salt particles ( $87 \%$ by mass; Weller et al., 2008). Although aerosol composition in summer is more variable, sea salt still accounts for a significant fraction $(50 \%$ by mass) but now with a large contribution from non-sea-salt sulfate $(27 \%$ by mass; Weller et al., 2008). Measurements at the coastal Antarctic McMurdo station show the persistent presence of sulfate aerosol throughout the year (Giordano et al., 2017). In the winter, these particles are highly aged. Sulfate aerosol then increases through the austral spring/summer due to enhanced emissions of dimethyl sulfide (DMS) and methanesulfonic acid (MSA) from phytoplankton in the Southern Ocean (Gibson et al., 1990; Giordano et al., 2017). Giordano et al. (2017) also report the presence of a sub- $250 \mathrm{~nm}$ aerosol population of unknown composition during the winter-to-summer transition. In addition, a study has observed a significant fraction of organic carbon ( $>10 \%)$ and lower contributions from sea salt $(<10 \%)$ in summer marine Antarctic aerosol (Virkkula and Teinil, 2006). Measurements in the Antarctic have found that the aerosol is highly hygroscopic in marine air masses (Mangold et al., 2017), while continental aerosol is less hygroscopic, which is consistent with a lower MSA fraction and the aging of marine organic components (Asmi et al., 2010). To date, Antarctic INP measurements have mostly been made at surface sites. Measurements of snowflake residuals at the South Pole identified the longrange transport of clays as the likely dominant source $(\mathrm{Ku}-$ mai, 1976). However, interpretation of these measurements is complicated due to secondary aerosol scavenging by the snowflakes and precipitation, meaning they contain particles in addition to the original nuclei. More recently, filter samples at the South Pole detected INPs that were active between -18 and $-27{ }^{\circ} \mathrm{C}$, with concentrations of $1 \mathrm{~L}^{-1}$ at $-23^{\circ} \mathrm{C}$. Mineral dusts transported from the Patagonian deserts were identified as the likely source (Ardon-Dryer et al., 2011). A synthesis of INP measurements prior to 1988 from the high southern latitudes $\left(>60^{\circ} \mathrm{S}\right)$ found mean concentrations between $2 \times 10^{-4}$ and $0.2 \mathrm{~L}^{-1}$ at $-15^{\circ} \mathrm{C}$ (Bigg, 1990). Given the general absence of other local INP sources, biogenic INPs may have a more important role in the Antarctic than in other regions. Biological species (pollen, bacteria, fungal spores and plankton) have been shown to act as INPs at significantly higher temperatures than mineral dusts $\left(>-15^{\circ} \mathrm{C}\right.$ ) (Möhler et al., 2007; Alpert et al., 2011; Murray et al., 2012; Amato et al., 2015; Wilson et al., 2015). However, Antarctic snowfall has been shown to be relatively depleted of biological INPs (Christner et al., 2008), and bacteria commonly found in sea ice may not be effective INPs (Junge and Swanson, 2008). The few in situ measurements of Antarctic clouds to date have suggested the importance of secondary ice processes (Grosvenor et al., 2012; Lachlan-Cope et al., 2016).

There is a clear need for more direct measurements to test and improve the representation of Antarctic clouds in climate/weather models. This paper presents both ground-based and airborne measurements of cloud and aerosol properties during the 2015 Microphysics of Antarctic Clouds (MAC) field campaign which is aimed at addressing this. Section 2 provides an overview of the campaign and the measurement techniques used. Section 3 presents a statistical overview of the aerosol and cloud observations using all available measurements. Section 4 discusses the key microphysical processes. Conclusions are presented in Sect. 5.

\section{Methods}

\subsection{Campaign and meteorological overview}

The MAC experiment comprised both airborne and groundbased measurements of cloud and aerosol properties. Ground-based measurements were performed at the Clean Air Sector Laboratory (CASLab), which is located at the Halley research station. Halley is a coastal Antarctic base on the Brunt Ice Shelf, approximately $30 \mathrm{~km}$ from the Weddell Sea $\left(75.6^{\circ} \mathrm{S}, 26.7^{\circ} \mathrm{W}\right)$. The CASLab is located $1 \mathrm{~km}$ south of the main Halley buildings and receives minimal pollution from the base and vehicle traffic due to the prevailing easterly wind (Jones et al., 2008). All CASLab measurements were filtered 


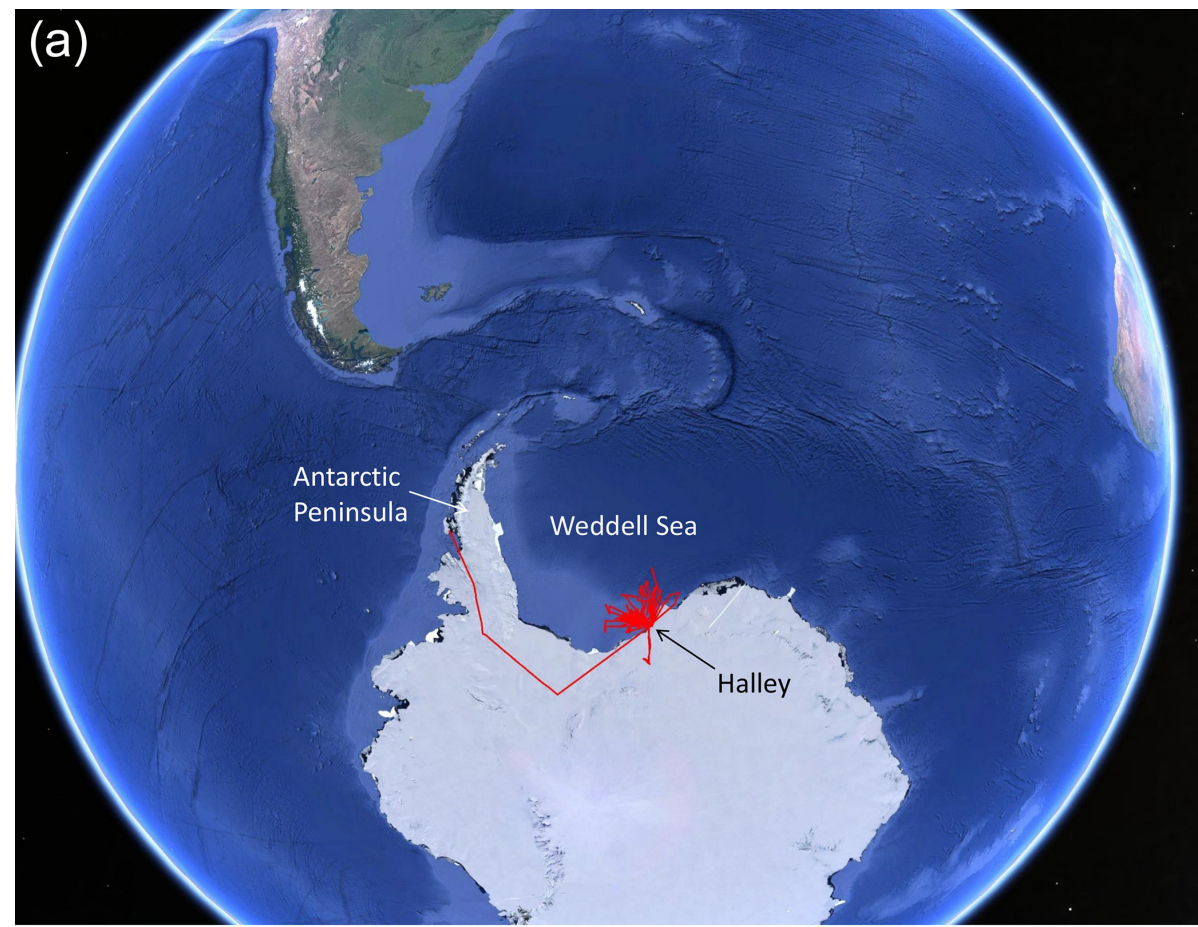

(b)

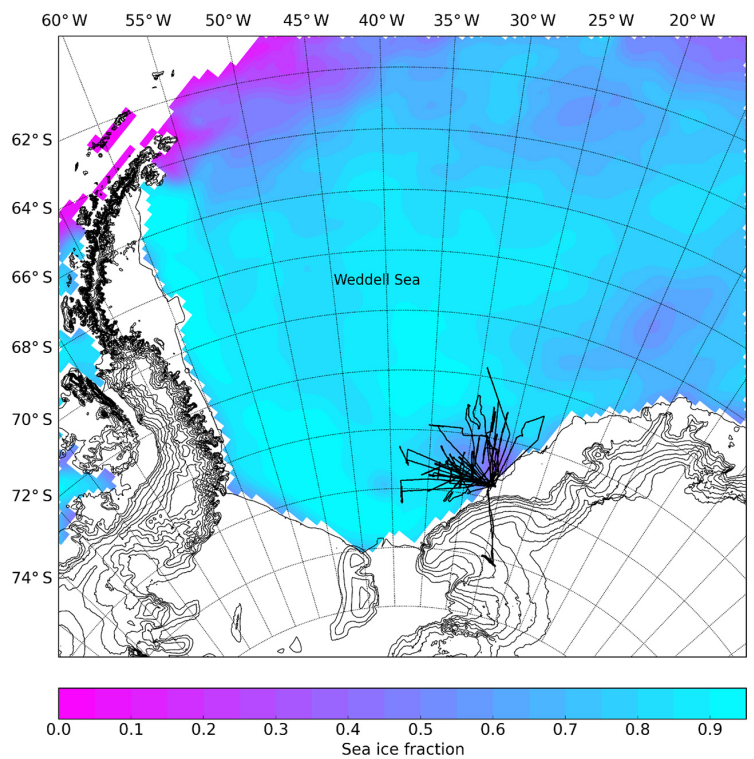

Figure 1. (a) Flight tracks during the MAC field project (source: Google Earth). Panel (b) shows the sea ice fraction on the Weddell Sea (Maslanik and Stroeve, 1999) during the experimental period.

using the wind direction to help remove any remaining influence from the base.

The airborne measurements were collected using the British Antarctic Survey's Twin Otter MASIN research aircraft (King et al., 2008). A total of 24 flights (a total of $80 \mathrm{~h}$ ) were performed during November and December 2015 from Halley. These flights have the nominal flight numbers 212 to 235 . The flights were predominantly performed over the Weddell Sea (see Fig. 1), which at this time and location was covered by a mixture of broken sea ice and polynyas. This is shown in Fig. 1 together with the sea ice fraction (Maslanik and Stroeve, 1999). One flight sampled clouds inland over the Antarctic continent (Flight 233). In addition, transit took place from Rothera research station on the Antarctic Peninsula (Flights 212 to 215); however, not all instruments were available during these transit flights. Since the aircraft was not pressurised, the measurements were restricted to altitudes below approximately $4000 \mathrm{~m}$. As a consequence, the major- 
Table 1. The height and temperature of cloud base and top for each flight. The ranges of altitudes in brackets are an estimate of the uncertainty in the cloud heights due to a combination of variability in the cloud and incomplete sampling. If multiple layers were present, unless noted otherwise, the height and temperatures given are for the main cloud layer sampled.

\begin{tabular}{|c|c|c|c|c|c|c|}
\hline Number & Date & Base altitude (m) & Top altitude (m) & $\begin{array}{l}\text { Base tempe- } \\
\text { rature }\left({ }^{\circ} \mathrm{C}\right)\end{array}$ & $\begin{array}{l}\text { Top tempe- } \\
\text { rature }\left({ }^{\circ} \mathrm{C}\right)\end{array}$ & Comment \\
\hline 216 & 21 Nov 2015 & $261(246-283)$ & $951(925-983)$ & -12.1 & -14.1 & Multiple layers \\
\hline 217 & 24 Nov 2015 & $330(296-366)$ & $662(621-700)$ & -9.8 & -12.3 & Multiple layers \\
\hline 218 & 27 Nov 2015 & $312(298-327)$ & $554(539-569)$ & -4.8 & -6.1 & $\begin{array}{l}\text { Main layer with broken layers } \\
\text { above }\end{array}$ \\
\hline 219 & 27 Nov 2015 & $375(316-441)$ & $870(847-890)$ & -4.7 & -7.8 & Single layer \\
\hline 220 & 28 Nov 2015 & $1143(1129-1154)$ & $1303(1289-1317)$ & -12.9 & -13.2 & Single layer \\
\hline 221 & 29 Nov 2015 & $157(124-202)$ & $530(499-564)$ & -6.0 & -6.6 & $\begin{array}{l}\text { Single layer with high cloud above } \\
(3000 \mathrm{~m})\end{array}$ \\
\hline 222 & 30 Nov 2015 & $170(151-201)$ & $603(573-635)$ & -6.8 & -8.5 & $\begin{array}{l}\text { Predominately single layer; partial } \\
\text { layer above }\end{array}$ \\
\hline 223 & 3 Dec 2015 & $262(247-277)$ & $745(712-771)$ & -7.1 & -9.5 & Multiple layers \\
\hline 224 & 6 Dec 2015 & $1056(1022-1090)$ & $4278(4253-4300)$ & -7.6 & -18.9 & $\begin{array}{l}\text { Frontal cloud multiple layers; cloud } \\
\text { top not sampled; height and temper- } \\
\text { ature ranges are for all layers sam- } \\
\text { pled }\end{array}$ \\
\hline 225 & 7 Dec 2015 & $694(680-718)$ & $1010(944-1066)$ & -5.0 & -5.7 & $\begin{array}{l}\text { Single layer with high cloud above } \\
(4000 \mathrm{~m})\end{array}$ \\
\hline 226 & 7 Dec 2015 & $1273(1230-1319)$ & $1866(1853-1873)$ & -5.4 & -6.8 & $\begin{array}{l}\text { Single layer with high cloud above } \\
(4000 \mathrm{~m})\end{array}$ \\
\hline 227 & 8 Dec 2015 & $88(68-107)$ & $417(372-455)$ & -5.8 & -6.9 & Single layer \\
\hline 228 & 9 Dec 2015 & $76(50-122)$ & $528(493-567)$ & -6.7 & -5.9 & $\begin{array}{l}\text { Single layer; second partial layer at } \\
1500 \mathrm{~m}\end{array}$ \\
\hline 229 & 9 Dec 2015 & & & & & No cloud sampled \\
\hline 230 & 10 Dec 2015 & $334(304-362)$ & $574(558-588)$ & -4.6 & -6.5 & Single layer \\
\hline 231 & 11 Dec 2015 & $293(279-321)$ & $1171(1158-1186)$ & -4.6 & -8.3 & $\begin{array}{l}\text { Predominantly single layer, partial } \\
\text { layer above }\end{array}$ \\
\hline 232 & 11 Dec 2015 & $554(516-601)$ & $1126(1108-1148)$ & -6.3 & -10.1 & Single layer with high cloud above \\
\hline 233 & 12 Dec 2015 & $1630(1600-1667)$ & $1857(1852-1861)$ & -14.1 & -15.4 & Single broken layer \\
\hline 234 & 13 Dec 2015 & $\begin{array}{r}409(387-428) \\
1489(1479-1499)\end{array}$ & $\begin{array}{r}710(700-720) \\
1785(1764-1804)\end{array}$ & $\begin{array}{r}-5.9 \\
-13.6\end{array}$ & $\begin{array}{r}-7.1 \\
-13.7\end{array}$ & $\begin{array}{l}\text { Lower layer } \\
\text { Higher layer not directly above } \\
\text { lower level }\end{array}$ \\
\hline 235 & 14 Dec 2015 & 954 (929-979) & $1432(1404-1461)$ & -9.9 & -13.9 & $\begin{array}{l}\text { Main layer sampled with broken } \\
\text { layers below }\end{array}$ \\
\hline
\end{tabular}

ity of clouds were sampled over the temperature range -11 and $-3{ }^{\circ} \mathrm{C}(79 \%)$. In total, $17 \%$ of in-cloud measurements were collected at temperatures below $-11^{\circ} \mathrm{C}$ and $4 \%$ at temperatures higher than $-3{ }^{\circ} \mathrm{C}$ and $17 \mathrm{~h}$ of sampling during the campaign were performed in clouds.

The clouds sampled were generally stratiform, with strong temperature inversions at cloud top. The exception to this was Flight 224, which sampled frontal clouds. Table 1 shows the altitude and temperature of cloud base/top for each flight. If multiple layers were present, unless otherwise noted, the height and temperatures are given for the layer where the majority of sampling took place. To show the meteorological setting for the campaign, Figs. S1-S20 in the Supplement show surface pressure charts from the ERA-Interim reanalysis (at 12:00 UTC on the given day; Dee et al., 2011) and HYSPLIT (Hybrid Single-Particle Lagrangian Integrated Trajectory; Stein et al., 2015) back trajectories for each flight. Back trajectory analysis showed that two broad regimes were present during the project. The earlier flights (up to Flight 223) generally sampled air masses that had travelled south over the Southern Ocean and Weddell Sea. Later in the campaign, there was a transition to air masses with greater influence from the Antarctic continent.

\subsection{Aircraft}

During MAC, the Twin Otter MASIN research aircraft was fitted with a range of in situ aerosol and cloud microphysical instrumentation. Cloud particle size distributions were derived using the images from two optical array probes (OAPs): a 2DS (2D stereo, SPEC Inc., USA; see Lawson et al., 2006) with a nominal size range of 10 to $1280 \mu \mathrm{m}(10 \mu \mathrm{m}$ pixel resolution) and a CIP-25 (cloud imaging probe, DMT Inc., USA; Baumgardner et al., 2001) with a size range of 25 to $1600 \mu \mathrm{m}$ 
( $25 \mu \mathrm{m}$ pixel resolution). The 2DS was not operated on the flights before Flight 218.

Particle size distributions over the size range from 0.5 to $50 \mu \mathrm{m}$ were recorded using a cloud aerosol spectrometer (CAS, DMT Inc., USA; Baumgardner et al., 2001). The CAS sizing was calibrated by the manufacturer using polystyrene latex (PSL) spheres $(<2 \mu \mathrm{m})$ and glass beads ( $>2 \mu \mathrm{m}$ ) (Baumgardner et al., 2014). During MAC, the sizing of the CAS's larger bins $(>10 \mu \mathrm{m})$ was also validated using reference glass calibration beads and shows little instrument drift.

The aircraft was also fitted with a cloud droplet probe (CDP-100, DMT Inc.) for observing cloud droplets between 3 and $50 \mu \mathrm{m}$ (Lance et al., 2010). Following the method detailed by Rosenberg et al. (2012), glass beads were used to determine the CDP's size bin centres and widths. The 2DS and CIP-25 were fitted with anti-shatter tips to minimise ice break-up on their leading edges (Korolev et al., 2011). For full details of the data processing and quality control of the 2DS and CIP-25 measurements, see Crosier et al. (2011) and Taylor et al. (2016). It should be noted that, in addition to the use of anti-shatter tips, an interarrival time algorithm was used to further reduce shattering artefacts on the 2DS and CIP-25 datasets. Ice mass content was determined from the 2DS and CIP-25 images using the Brown and Francis (1995) mass-diameter relationship. Unless stated otherwise, all flight data presented have been averaged to $10 \mathrm{~s}$ intervals. A linear fit to the number concentrations derived by the CDP and CAS where their size ranges overlap has the following equation: $\mathrm{CDP}=0.87 \times \mathrm{CAS}+1.7 \mathrm{~cm}^{-3}\left(R^{2}=0.83\right)$. Similarly, the regression equation for the CIP and 2DS is $\mathrm{CIP}=0.65 \times 2 \mathrm{DS}+0.7 \mathrm{~cm}^{-3}\left(R^{2}=0.34\right)$.

Following Crosier et al. (2011), 2DS and CIP-25 images were classified based on a geometric analysis of their circularity, $C$ :

$C=\frac{P^{2}}{4 \pi A}$,

where $P$ is the particle perimeter and $A$ is its area. Particles containing less than 50 pixels (equivalent to a diameter of approximately $80 \mu \mathrm{m}$ for the 2DS and $200 \mu \mathrm{m}$ for the CIP25) were not classified since they contain insufficient pixels to accurately determine their shape. Particles with circularity values less than 1.2 were classified as low irregular (LI) and are indicative of liquid drops. Circularity values greater than 1.4 are associated with ice crystals and are classified as high irregular (HI). Visual inspection of the LI and $\mathrm{HI}$ images confirmed that they were almost all liquid droplets and ice crystals, respectively. Circularities between 1.2 and 1.4 are classified as medium irregular (MI). Interpretation of the MI category with respect to the particle phase is more ambiguous than the other categories. In general, the MI images were of quasi-spherical ice crystals, such as recently frozen drops; however, they may also include some poorly imaged liquid drops that should be classified as LI. During MAC, the

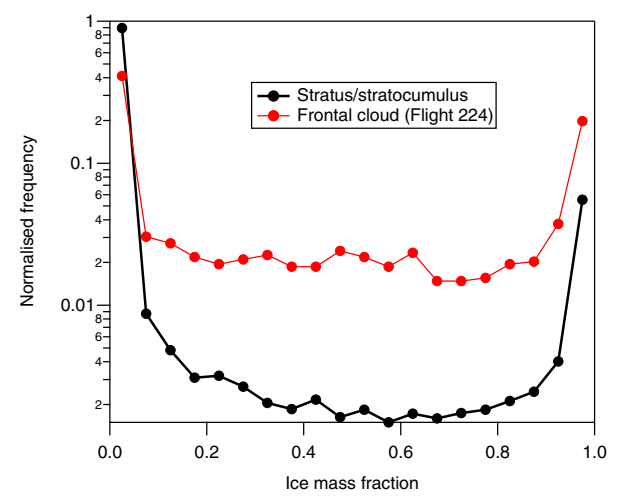

Figure 2. Frequency distribution of the $1 \mathrm{~Hz}$ cloud ice mass fraction measurements.

concentration of MI particles was generally significantly less than HI particles. The mean ratio of $\mathrm{HI}$ : MI for the campaign was 7 (see also Sect. 3.1). This suggests that the HI concentration is likely a good proxy for the ice crystal concentration.

Aerosol instrumentation on the aircraft included a GRIMM optical particle counter (GRIMM model 1.109) capable of detecting aerosol particles over the size range from 0.25 to $32 \mu \mathrm{m}$. The GRIMM sampled through a Brechtel model 1200 isokinetic aerosol inlet with a $>95 \%$ sampling efficiency for particles in the size range 0.01 to $6 \mu \mathrm{m}$. Inlet losses only become significant for particles $>6 \mu \mathrm{m}$, and here we only consider the concentration of particles below $2 \mu \mathrm{m}$. Total aerosol concentrations of particles $>10 \mathrm{~nm}$ in size were determined using a condensation particle counter (CPC, TSI Inc. model 3772).

The aircraft was also fitted with instrumentation to measure temperature, turbulence, humidity, radiation and surface temperature (see King et al., 2008 for full details).

\subsection{Ground site measurements}

Aerosol instrumentation was installed at the CASLab sampling from its central aerosol stack (Jones et al., 2008) for the measurement period from 27 November to 15 December 2015. A differential mobility analyser (DMA, TSI Inc.) was used to generate a quasi-monodisperse aerosol flow. The DMA performed 27 discrete steps over the aerosol size range from 30 to $500 \mathrm{~nm}$. Downstream of the DMA, the flow $\left(1 \mathrm{~L}^{-1}\right)$ was split isokinetically between a cloud condensation nuclei counter $(\mathrm{CCN}$, DMT Inc. model $\mathrm{CCN}-$ 100 ) and a CPC. The CCN concentration was measured at supersaturations of $0.08,0.20,0.32,0.41$ and $0.53 \%$. The activated cloud droplet fraction was determined by the ratio of activated particles from the $\mathrm{CCN}$ to the total number of particles measured by the CPC. The dry diameter at which $50 \%$ of particles were activated $\left(D_{50}\right)$ was determined by fitting a sigmoid curve to the activated fraction size spectrum (Whitehead et al., 2016). The total CCN concentration was determined by integrating the concentration of particles 
larger than $D_{50}$. The hygroscopicity parameter $\kappa$ was derived from $\kappa$-Köhler theory using the $D_{50}$ and supersaturation values (Petters and Kreidenweis, 2007).

The DMA and CCNc were calibrated at the beginning and end of the campaign (Good et al., 2010). The DMA was size calibrated using NIST traceable PSL spheres. Ammonium sulfate and sodium chloride were used to calibrate the $\mathrm{CCNc}$ supersaturations, by comparing measured values to theoretical ones from the Aerosol Diameter Dependent Equilibrium Model (ADDEM) (Topping et al., 2005).

Additional measurements were provided by an aerodynamic particle sizer (APS, TSI Inc., model 3321) which provided aerodynamic particle size concentration measurements over the size range $0.5<D<20 \mu \mathrm{m}$ and in the size range $0.3<D<20 \mu \mathrm{m}$ from simultaneous aerosol scattering cross-section measurements. Total aerosol concentrations $(D>10 \mathrm{~nm}$ ) were determined using a CPC (TSI Inc. model 3776).

Continuous measurements of airborne bio-fluorescent particle concentrations (primary biological, mixed biological and non-biological) were also made at CASLab using a wideband integrated bioaerosol spectrometer (WIBS model Dstl3). Measurements from this instrument are described in detail in Crawford et al. (2017).

\subsection{Numerical Atmospheric Dispersion Modelling Environment (NAME)}

To examine how aerosol and cloud properties vary with air mass history, we perform back trajectory analysis using the UK Met Office's NAME model (Numerical Atmospheric Dispersion Modelling Environment) (Jones et al., 2007) using Met Office Unified Model (UM) meteorological fields. The 5-day retroplumes were determined by releasing 10000 particles in the model at locations coincident with the aircraft's position. Here, we examine the relative sensitivity to surface emissions from the following regions: the Antarctic continent, sea ice, Southern Ocean, ice shelf and South America. The number of particles near the surface $(0$ to $100 \mathrm{~m}$ ) over each geographic region was summed every $15 \mathrm{~min}$ as the particles were dispersed 5 days backwards in time. For each region, the time integration of particles over the region was divided by the total number of particles appearing in the whole domain to determine fractional contributions (see Fleming et al., 2012). Shape files representing the monthly averaged sea ice extent from Polarview and geographical contour files for the Antarctic continent, the permanent sea ice (ice shelves and permanent sea ice) and the South American continent were used to determine the passageway of the air masses at surface levels sampled by the aircraft. This analysis was repeated for particles released at $60 \mathrm{~s}$ intervals along the flight track to determine a time series of contributions from each geographic region.

\section{Results}

\subsection{Cloud microphysics}

The following section presents a broad overview of the microphysical measurements during the MAC field campaign. For this analysis, "in-cloud" measurements were determined as periods when the liquid water content (LWC) was greater than $0.01 \mathrm{~g} \mathrm{~m}^{-3}$ or when particles were detected by the $2 \mathrm{DS}$. Flight 224 is excluded from this bulk analysis since this flight sampled frontal clouds, while the other flights sampled shallow layer clouds. The ice mass fraction (IMF) is calculated as the ratio of the ice mass to the total condensed water. Here, the ice mass is taken as the sum of the HI and MI 2DS categories, while the liquid mass is taken as the sum of the CAS droplets $(>3 \mu \mathrm{m})$ and the 2DS LI category. Ice mass fractions of 0 and 1 represent fully liquid and glaciated conditions, respectively. Figure 2 (black line) shows the frequency distribution of ice mass fraction based on all $1 \mathrm{~Hz}$ measurements in layer clouds sampled during MAC. As can be seen in Fig. 2, the clouds were dominated by liquid water. Ice mass fractions between 0 and 0.1 were observed $90 \%$ of the time, while only $6 \%$ of cases had values between 0.9 and 1 . Figure $3 \mathrm{a}$ shows the ice mass fraction as a function of height. For altitudes below approximately $1000 \mathrm{~m}$ (all altitudes are given in metres above mean sea level), there is a general trend of glaciated conditions becoming more prevalent with decreasing altitude (and increasing temperature). At temperatures higher than $-3^{\circ} \mathrm{C}$, glaciated conditions (IMF greater than 0.9 ) were responsible for $15 \%$ of observations, compared to $7 \%$ at temperatures between -8 and $-3{ }^{\circ} \mathrm{C}$. Above $2000 \mathrm{~m}$, glaciated regions become more frequent with increasing altitude; however, this is based on comparatively few observations.

Figure $3 \mathrm{~b}$ shows ice mass fraction measurements in single layer clouds as a function of the normalised position within the cloud, $\mathrm{Zn}$.

$\mathrm{Zn}=\frac{Z-Z_{\mathrm{B}}}{Z_{\mathrm{T}}-Z_{\mathrm{B}}}$,

where $Z$ is the altitude; $Z_{\mathrm{B}}$ and $Z_{\mathrm{T}}$ are the cloud base and cloud top altitude, respectively. We note that there is some uncertainty in determining cloud base/top due to variability in the cloud and also incomplete sampling (this uncertainty is estimated in Table 1). The clouds were dominated by liquid drops throughout, while ice was more prevalent lower in the clouds. The relationship between ice mass fraction (IMF) and $\mathrm{Zn}$ over the range $0<\mathrm{Zn}<1$ can be approximated by the following equation:

$\mathrm{IMF}=0.177+0.360 \mathrm{Zn}+0.244 \mathrm{Zn}^{2}$.

This is shown as a red line in Fig. 3b. Figure $3 c$ and d show that both liquid water content and cloud droplet effective radius increased closer to cloud top. The effective radius in- 

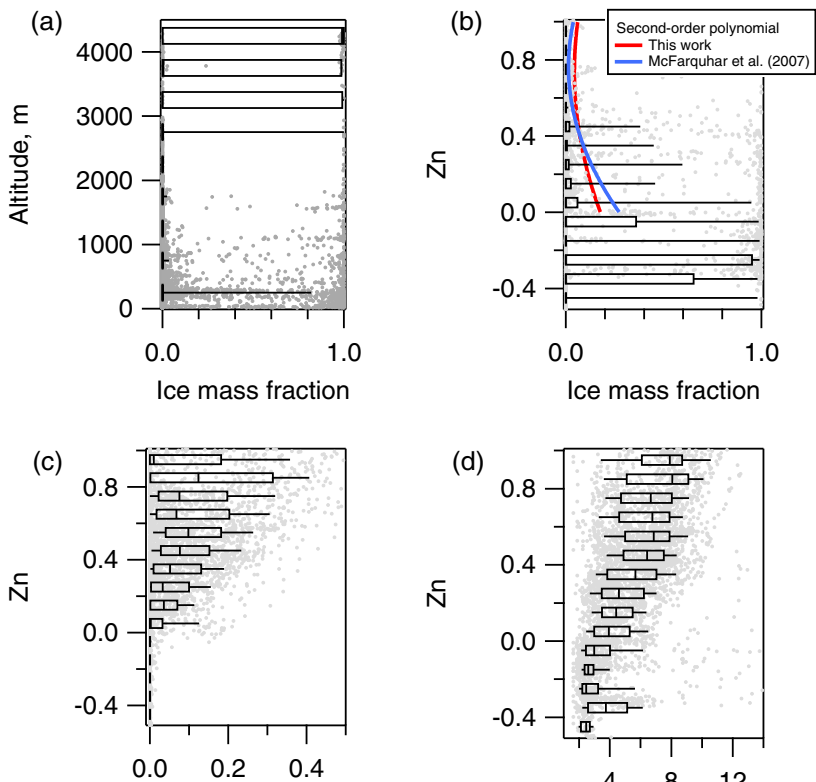

Liquid water content, $\mathrm{g} \mathrm{m}^{-3}$

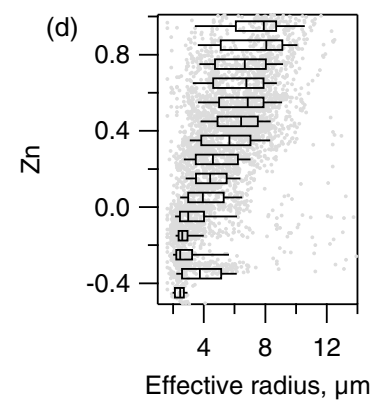

Figure 3. (a) Ice mass fraction as a function of altitude and (b) normalised position within the cloud (Zn). Panels (c) and (d) show similar plots for liquid water content and effective radius from the CAS probe. Boxes are the 25 th and 75 th percentiles; the whiskers are the 10th and 90th percentiles.

creased from $4 \pm 2 \mu \mathrm{m}$ near cloud base to $8 \pm 3 \mu \mathrm{m}$ near cloud top.

Measurements in Arctic stratus/stratocumulus generally find these clouds to be similarly dominated by liquid drops (McFarquhar and Cober, 2004; McFarquhar et al., 2007; Lloyd et al., 2015a). A polynomial relationship derived during the Mixed-Phase Arctic Cloud Experiment (M-PACE) is shown as a blue line in Fig. 3b (McFarquhar et al., 2007). McFarquhar et al. (2007) show a trend of increasing IMF with increasing distance from cloud top (and increasing temperature). Glaciated conditions were observed during $23 \%$ of their measurements. This is significantly more than during MAC, possibly due to lower INP concentrations available for primary ice development in the Antarctic compared to the Arctic, but differing sampling strategies may also contribute to this difference.

Flight 224 sampled cloud layers at the rear of an occluded front that was associated with a low pressure system north of Halley. Several layers were observed between -19 and $-1{ }^{\circ} \mathrm{C}$ with ice crystals precipitating between the layers. As shown in Fig. 2 (red line), ice was more frequently observed in these clouds than during the flights where stratocumulus/stratus clouds were sampled. A total of $24 \%$ of measurements had ice mass fractions between 0.9 and 1, while $32 \%$ of observed ice mass fraction values were between 0.1 and 0.9 . Droplet number concentrations were comparatively low with a mean of $40(29$ at $1 \sigma) \mathrm{cm}^{-3}$.
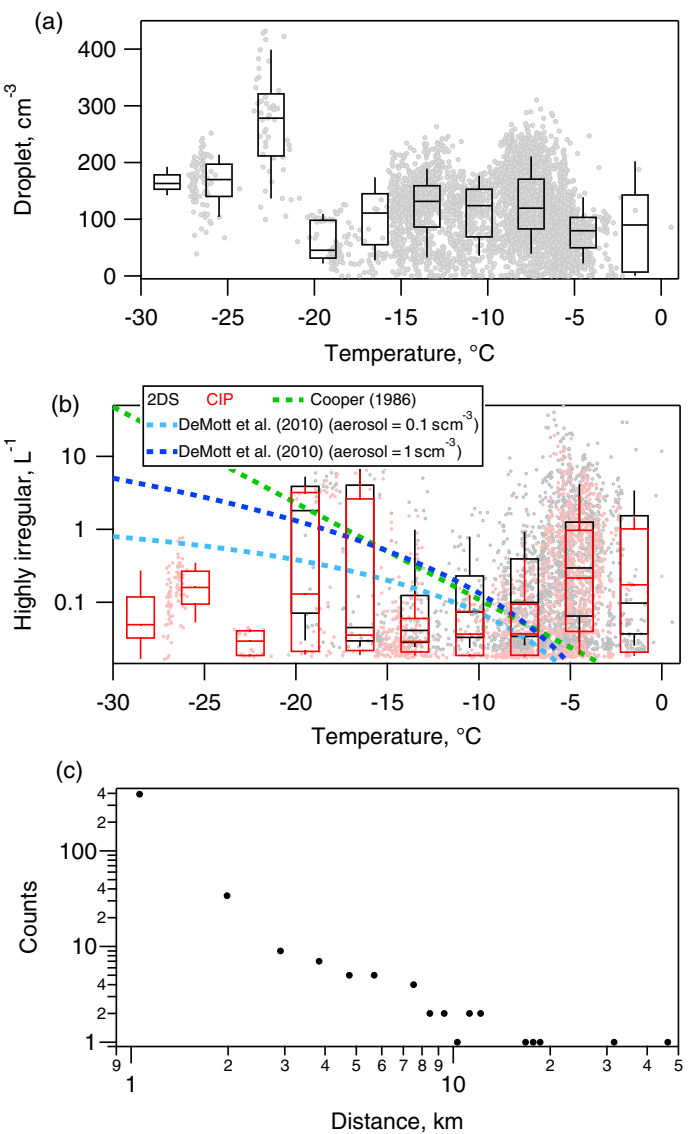

Figure 4. Box-and-whisker plots summarising in-cloud measurements (averaged over $10 \mathrm{~s}$ ) as a function of temperature. Panel (a) shows the concentration of cloud droplets $\left(\mathrm{cm}^{-3}\right)$, measured by CAS, while (b) shows the concentration of ice particles measured by 2DS and CIP-25, based on those classified as highly irregular (see text for details). The concentrations of INPs predicted by the DeMott et al. (2010) parameterisation with high $\left(1 \mathrm{scm}^{-3}\right)$ and low $\left(0.1 \mathrm{scm}^{-3}\right)$ aerosol input are shown as dark and light blue lines, respectively, in panel (b). The green line is the predicted ice particle concentration according to the Cooper (1986) parameterisation. Panel (c) shows a frequency plot of the flight distance while continuously sampling ice.

The droplet number concentration as a function of temperature is shown in Fig. 4a. This was found to be relatively consistent and temperature independent during the campaign, with a median of $113 \mathrm{~cm}^{-3}$ and an interquartile range of $86 \mathrm{~cm}^{-3}$. An exception to this is Flight 217, when anomalously high droplet concentrations were observed at $-23^{\circ} \mathrm{C}$ (mean $310 \mathrm{~cm}^{-3}$ ). The 2DS was not available during this flight but the CIP observations suggest that ice was not present in this cloud. The reason for the enhanced droplet concentrations is not clear; however, the aerosol concentrations below the cloud layer was similarly elevated with the CPC recording concentrations of over $1200 \mathrm{scm}^{-3}$, compared to the median for the campaign of $408 \mathrm{scm}^{-3}$. Back 
trajectory analysis showed that in the previous days this air mass travelled over the Southern Ocean from South America.

The cloud droplet concentrations during MAC are found to be comparable with previous observations from the Antarctic Peninsula (Lachlan-Cope et al., 2016) and also Arctic summer stratocumulus (Lloyd et al., 2015a). Droplet concentrations over the Antarctic Peninsula varied between 60 and $200 \mathrm{~cm}^{-3}$ (Lachlan-Cope et al., 2016). Concentrations on the eastern side of the peninsula were moderately higher than on the west, which may be due to the greater sea ice coverage on the eastern side. It has been suggested that sea ice may provide a more efficient source of sea-salt aerosol, and therefore CCN, than open waters (Yang et al., 2008). Recent measurements and modelling found that sea ice made a significant contribution to the winter sea-salt aerosol loading at coastal (Dumont d'Urville) and central (Concordia) East Antarctic sites (Legrand et al., 2016).

The number of highly irregular particles observed by the 2DS/CIP-25 can be used as a proxy for the number of ice crystals; this is shown as a function of temperature in Fig. 4b. Box-and-whisker plots show statistics for those regions of the cloud where ice is present (i.e. excluding regions with only liquid cloud water). The temperature bins -21 to $-15^{\circ} \mathrm{C}$ in Fig. $4 \mathrm{~b}$ show the highest concentration of ice crystals. However, these measurements come from only one flight (Flight 226) where the base $(4000 \mathrm{~m})$ of high clouds was sampled. These crystals (predominantly rosettes and aggregates) are highly likely to have been nucleated at lower temperatures higher up in the cloud which then sedimented down to be sampled by the aircraft. At temperatures greater than $-15^{\circ} \mathrm{C}$, there is a trend of the ice crystal concentrations showing greater variability and higher median concentrations with increasing temperature. Ice in the clouds tended to occur in small patches. A histogram of the spatial extent of ice patches shows that they increase in frequency with decreasing length up to the maximum resolvable by the 2DS measurements (a sampling frequency of $10 \mathrm{~s}$ corresponds to a spatial scale of about $600 \mathrm{~m}$; Fig. 4c).

Previous observations of Arctic mixed-phase clouds found that the presence of precipitating ice particles $(>400 \mu \mathrm{m})$ was associated with the number of large drops $(>30 \mu \mathrm{m})$; however, the precise nucleation mechanism through which this occurs is uncertain (Lance et al., 2011). To identify if a similar relationship was present during MAC, Fig. 5a and b show the relationship between the 2DS HI and the 2DS LI particles (droplets larger than approximately $80 \mu \mathrm{m})$. Figure $5 \mathrm{c}-\mathrm{f}$ show similar plots for the CAS measurements of droplets larger than 30 and $20 \mu \mathrm{m}$, respectively. Figure 5a, c and e show measurements at temperatures lower than $-8^{\circ} \mathrm{C}$, and Fig. $5 \mathrm{~b}, \mathrm{~d}$ and $\mathrm{f}$ show those in the range -8 to $0^{\circ} \mathrm{C}$. The HI concentrations are binned based on the droplet concentration, and the 25th, 50th and 75th percentiles are shown as black lines. When examining statistics for all stratus flights, we find no evidence that the ice concentrations increase due to the presence of large drops. However, any relationship may be obscured as drops are depleted by ice crystal growth through riming and the Wegener-Bergeron-Findeisen process.

Similar results are found when case studies for individual flights are examined. Figure 6a shows a comparison between the particle size distributions for three periods with quite different degrees of glaciation during a constant altitude run at $-5^{\circ} \mathrm{C}$ during Flight 218 . Time series of the microphysical properties during this run are shown in Fig. 7. During this run, there were patches of ice with concentrations of several crystals per litre and regions where no ice was present. However, there are no distinct differences in the particle size distributions for particles $<100 \mu \mathrm{m}$ for these three cases. Figure $6 \mathrm{~b}$ shows a similar plot for a constant altitude run at $-6{ }^{\circ} \mathrm{C}$ during Flight 219 . During times with very high ice concentrations (2DS HI up to $50 \mathrm{~L}^{-1}$, blue line), the droplets $\left(10 \mathrm{~s}\right.$ minimum of $\left.11 \mathrm{~cm}^{-3}\right)$ are depleted compared to the cases when the 2DS HI concentration was 1 and $0 \mathrm{~L}^{-1}$ (approximately $100 \mathrm{~cm}^{-3}$ ).

\subsubsection{Ice crystal images}

Inspection of the cloud particle images shows that at temperatures higher than $-10^{\circ} \mathrm{C}$ columnar crystals appear as the dominant ice crystal habit, with irregular rimed crystals also widespread. This is illustrated by Fig. 8a with example images from Flight 218 at $-5^{\circ} \mathrm{C}$. Measurements in Arctic clouds at similar temperatures show that they are similarly dominated by columnar crystals (Lloyd et al., $2015 \mathrm{a}$ ). Figure $8 \mathrm{~b}$ shows images at $-15^{\circ} \mathrm{C}$ collected in a single layer cloud over the Antarctic continent, approximately $300 \mathrm{~km}$ south of Halley (Flight 233). This cloud had some columns/needles but also a high proportion of plates and stellar crystals. At the lowest sampled temperatures of $-20^{\circ} \mathrm{C}$ (Fig. 8c, Flight 226), the ice mostly consists of rosettes and irregular crystals, which may be aggregates. However, measurements at these low temperatures were relatively infrequent, and the ice may have been nucleated at lower temperatures higher in the cloud.

\subsection{Aerosol}

Vertical profiles of the out-of-cloud aerosol measurements made by the aircraft are shown in Fig. 9. Out-of-cloud measurements were selected as periods when the LWC was less than $0.001 \mathrm{~g} \mathrm{~m}^{-3}$ and when the 2DS was not detecting particles. Contributions from large, swollen aerosol particles were also removed when the relative humidity was higher than $90 \%$. Figure 9a shows aerosol concentrations over the size range from 0.5 to $1.5 \mu \mathrm{m}$ as observed by the CAS and GRIMM probes. This size range of aerosols has been shown to best represent the concentration of INPs in many locations around the world (DeMott et al., 2010). Concentrations within this size range decrease significantly with increasing height, as would be expected, through sea spray 

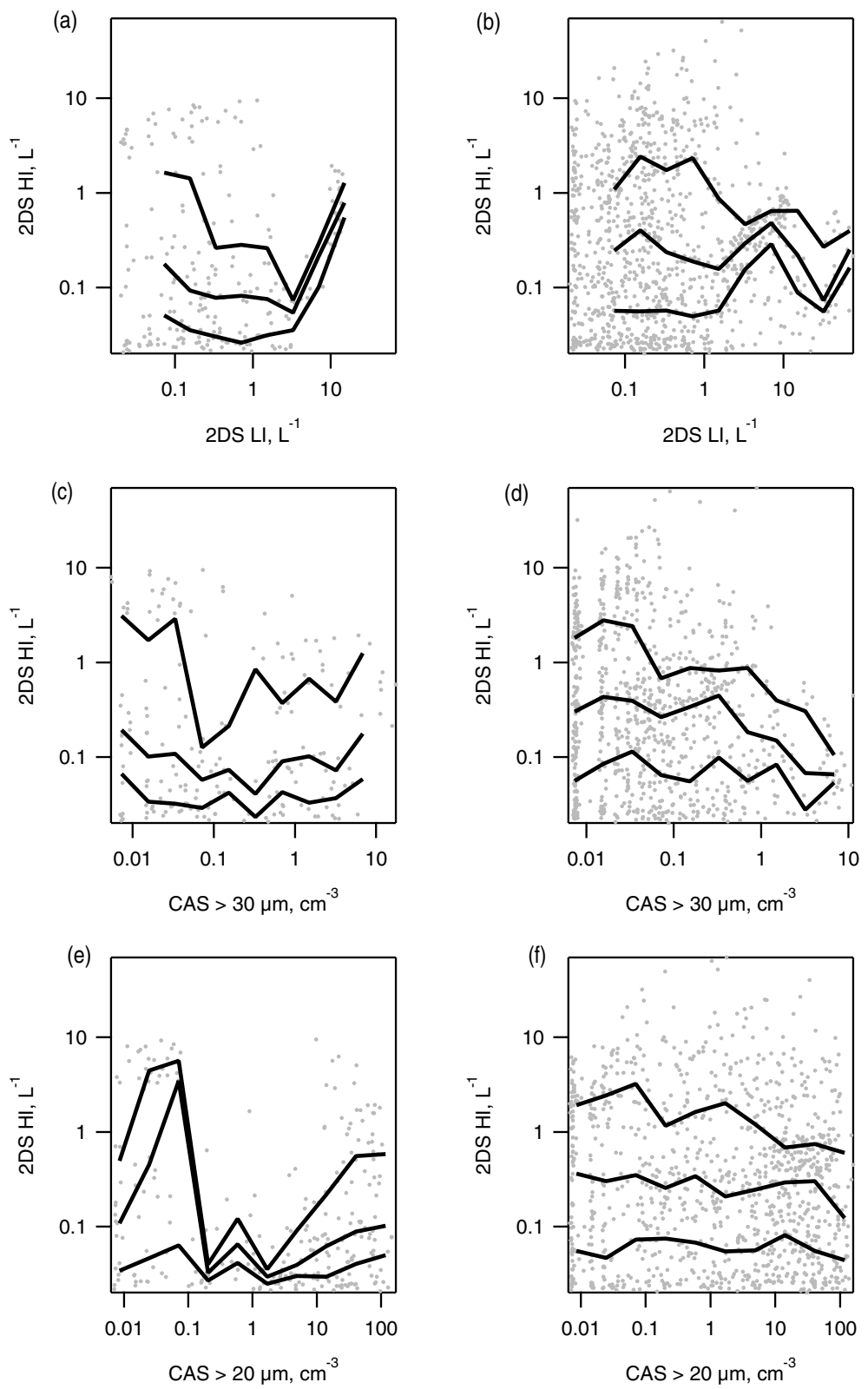

Figure 5. (a, b) The relationship between the concentration of highly irregular (2DS HI) particles and low irregular particles (2DS LI) (low irregular particles greater than approximately $80 \mu \mathrm{m}$ ). Panels (c-f) show the relationship with the concentration of droplets larger than 30 and $20 \mu \mathrm{m}$, respectively. Panels (a), (c) and (e) show measurements at temperatures lower than $-8^{\circ} \mathrm{C}$ and (b), (d) and (f) show those in the range -8 to $0{ }^{\circ} \mathrm{C}$. The black lines are the 25 th, 50th and 75 th percentiles of the $2 \mathrm{DS}$ HI concentration for each droplet concentration bin.

aerosol being rapidly removed by cloud processing or sedimentation. Previous measurements over the Antarctic Peninsula also found that aerosols in this size range decreased with height and ranged between 0.1 and $0.3 \mathrm{~cm}^{-3}$ above approximately $2500 \mathrm{~m}$. Total aerosol concentrations, measured by the CPC during MAC, had a median value for the campaign of $408 \mathrm{scm}^{-3}$ (standard centimeters; at standard temperature and pressure) and an interquartile range of $260 \mathrm{scm}^{-3}$.

During MAC, episodic periods were observed with total aerosol concentrations in excess of $1000 \mathrm{scm}^{-3}$. These were often observed above cloud layers. The flights were designed to focus on cloud regions, so they may not represent a truly unbiased sample of the atmosphere, but the results do suggest a link between the observations of high aerosol concentrations and the presence of clouds. The limited spatial coverage of the aircraft measurements makes quantifying the extent of these layers uncertain; however, they appear to extend over a few tens of kilometres to a hundred kilometres. At least two instances (Flights 218 and 219; see Fig. 10) suggest a large layer extending beyond the cloud edge, pointing at the pos- 

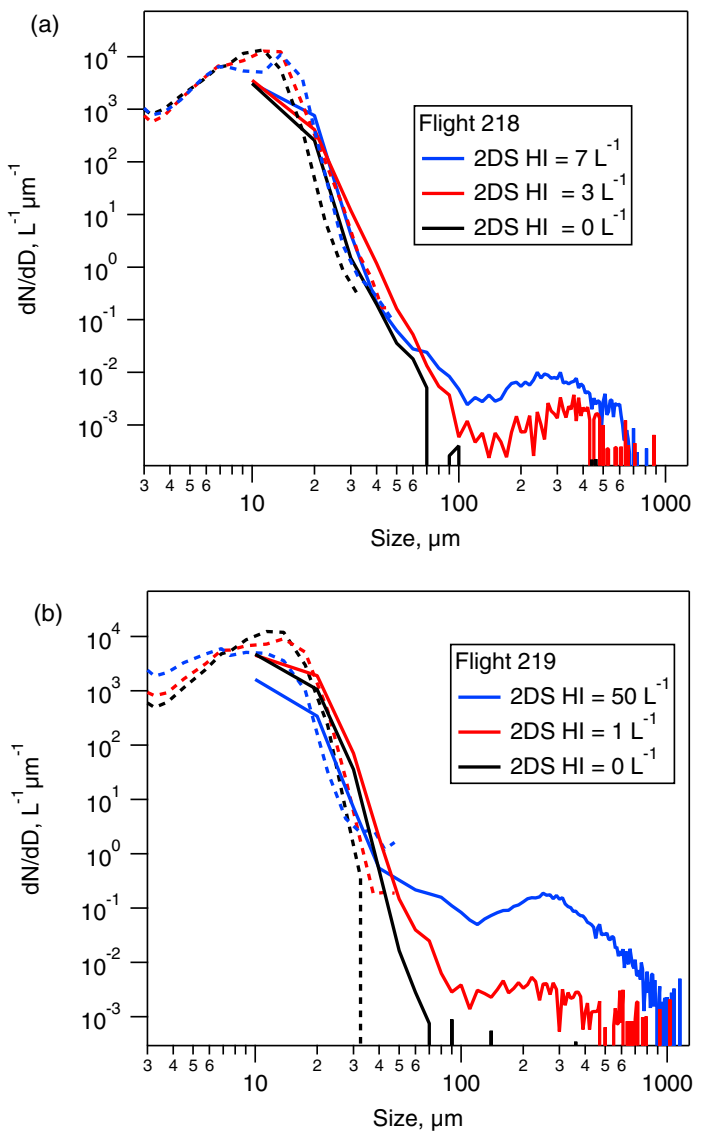

Figure 6. (a) Comparison between the particle size distributions for three regions sampled in the constant altitude run at $-5^{\circ} \mathrm{C}$ during Flight 218; these are where the concentration of highly irregular particles (2DS HI) was $7 \mathrm{~L}^{-1}$ (16:04 GMT), $3 \mathrm{~L}^{-1}$ (15:58 GMT) and $0 \mathrm{~L}^{-1}(15: 52 \mathrm{GMT})$. Time series of the microphysical measurements during this run are shown in Fig. 7. Panel (b) shows a similar plot for a run at $-6^{\circ} \mathrm{C}$ during Flight 219 when the 2DS highly irregular concentration was 50,1 and $0 \mathrm{~L}^{-1}$. Dashed lines show measurements from the CAS and solid lines are from the 2DS.

sibility of layers independent from clouds. The peak concentration usually occurred in the region up to $200 \mathrm{~m}$ above the cloud top (e.g. Flight 219). Some layers showed a clear drop in relative humidity (e.g. from 90 to $30 \%$ during Flights 220, 221 and 222) generally related to a clear temperature inversion, while other layers showed a much smaller decrease (by $10 \%$ ) in relative humidity compared to the cloud underneath (e.g. Flights 217, 218 and 219). No clear systematic relationship was observed with respect to the vertical wind velocity (turbulence). The role of these particles as CCN/INPs is currently uncertain due to the lack of information about their composition.

Average total concentrations of UV fluorescent aerosols (measured at CASLab with the WIBS) over the campaign period were $\sim 1 \mathrm{~L}^{-1}$, which was $<2 \%$ of the total particle concentration. Of these, $0.01 \mathrm{~L}^{-1}$ were identified as likely pri- mary biological aerosols. During some easterly and westerly wind events, however, enhanced concentrations of the order of $5(\mathrm{SD}=7)$ could be observed (Crawford et al., 2017).

\subsection{Cloud condensation nuclei}

Figure 11c summarises the $\mathrm{CCN}$ measurements at the CASLab. It shows the $\mathrm{CCN}$ at five different supersaturations $(0.08,0.20,0.32,0.41$ and $0.53 \%)$. The hygroscopicity parameter $\kappa$ is used to examine the effect chemical composition has on the CCN activity of aerosol particles. The derived $\kappa$ values represent the average hygroscopicity of the volume-weighted fractions of the individual aerosol components. Non-hygroscopic components have a $\kappa$ value of 0 . Highly active CCN salts have $\kappa$ values between 0.5 and 1.4; sodium chloride $(\mathrm{NaCl})$ has a $\kappa$ of 1.28 (measurement range 0.91 to 1.33 ). Organic species have values generally between 0.01 and 0.5 (Petters and Kreidenweis, 2007). The median $\kappa$ value during MAC was 0.66 (interquartile range of 0.38 , mean of 0.70 ), suggesting that this location is dominated by hygroscopic components, such as sea-salt and sulfate. Andreae and Rosenfeld (2008) review CCN measurements and find that $\kappa$ values from marine locations generally cover a relatively narrow range of $0.7 \pm 0.2$, compared to $0.3 \pm 0.1$ for continental aerosols. A global model study subsequently presented a mean $\kappa$ value of $0.92(0.09$ at $1 \sigma)$ at the surface and $0.80(0.17$ at $1 \sigma)$ within the boundary layer over the Southern Ocean (Pringle et al., 2010), only marginally higher than our MAC observations.

As shown in Fig. 11, there was a period of increased hygroscopicity on 28 and 29 November 2015, with a median $\kappa$ of 1.13 on 29 November. During this period, there was a westerly wind. This changed to an easterly on 30 November 2015, which coincided with a decrease in hygroscopicity to a median $\kappa$ for 30 November of 0.36 . Between the approximate headings of 210 to $25^{\circ}$, the CASLab lies between 30 and $60 \mathrm{~km}$ from the Weddell Sea. In contrast, within the sector of 30 to $60^{\circ}$, it lies several hundred kilometres across the Brunt Ice Shelf from the Weddell Sea. To the south-east of the CASLab lies the Antarctic continent. HYSPLIT trajectories indicate over the past 5 days the air mass sampled on 28 and 29 November 2015 had passed over sea ice/open water regions. However, after 30 November 2015, the hygroscopicity was relatively consistent and did not show a significant relationship with the wind direction or air mass history. For example, on 14 and 15 December 2015, there was a westerly wind but the median $\kappa$ for these days of 0.66 and 0.65 , respectively, was similar to the campaign median (0.66).

\subsection{Ice nucleating particles}

INPs could not be directly measured on the aircraft during MAC. Instead, we compare the cloud ice crystal concentrations with two parameterisations that are commonly used to predict INP concentrations. DeMott et al. (2010) com- 


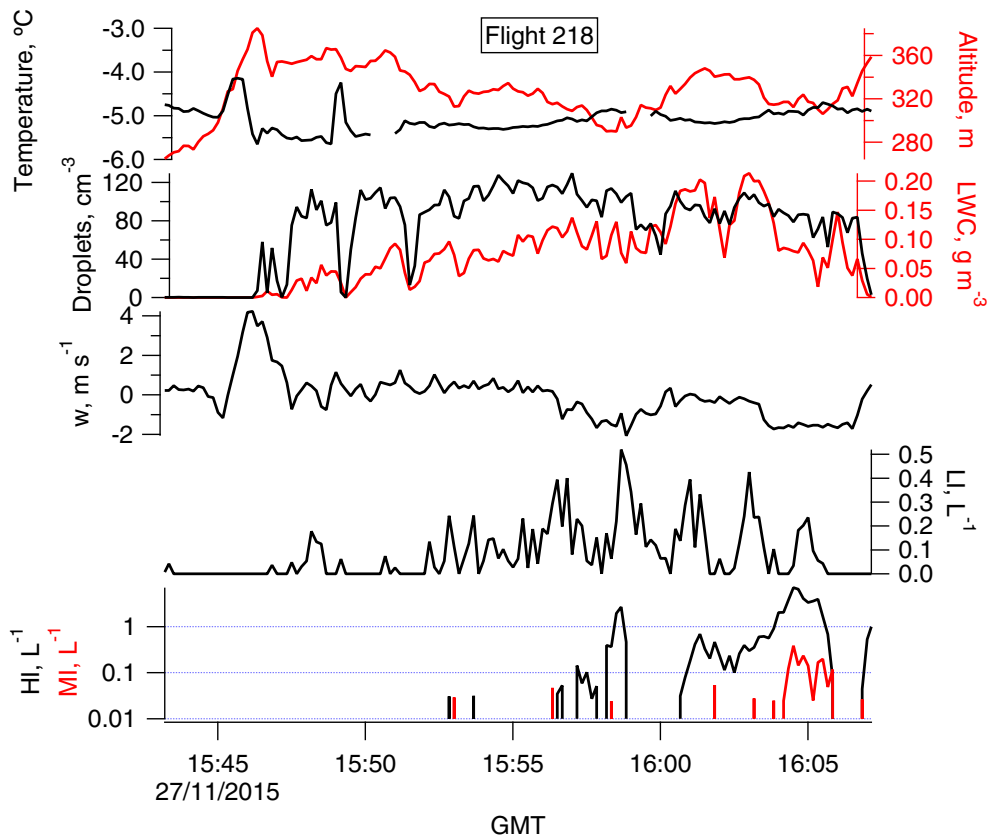

Figure 7. Time series of microphysical parameters during a constant altitude run at $-5^{\circ} \mathrm{C}(400 \mathrm{~m})$ during Flight 218 .

piled INP measurements from a range of locations around the world and derived a relationship using aerosol concentrations (within the size range 0.5 to $1.6 \mu \mathrm{m}$ ) and temperature that could explain the INP variability within their dataset to better than a factor of 10 . For a broad comparison with the MAC dataset, we evaluate DeMott et al. (2010) for high $\left(1 \mathrm{scm}^{-3}\right.$, dark blue lines; Fig. 4b) and low $\left(0.1 \mathrm{scm}^{-3}\right.$, light blue lines; Fig. 4b) aerosol cases. Cooper (1986) describes a simple INP parameterisation using only the ambient temperature, which is often used in the Weather Research and Forecasting model (WRF) (Morrison et al., 2009). The concentration of INPs from Cooper (1986) is shown as a red line in Fig. 4b. It should be noted that neither of these parameterisations used Antarctic measurements. Given the marine location of the flights, it is likely that these parameterisations may represent overestimates of the true INP concentration, since the number of INPs in sea spray aerosol is generally several orders of magnitude lower than the number of INPs in aerosol in the continental boundary layer (DeMott et al., 2015). The DeMott et al. (2010) parameterisation was derived using measurements at temperatures lower than $-9^{\circ} \mathrm{C}$, while Cooper (1986) used measurements below $-5^{\circ} \mathrm{C}$. For comparison, they are extrapolated to higher temperatures and are therefore subject to increased uncertainty.

As shown in Fig. 4b, given the uncertainty in both parameterisations and the challenges with making a direct comparison with the measurements, it is plausible that the observed ice concentrations at temperatures lower than about $-10^{\circ} \mathrm{C}$ could be explained by primary ice production. However, above this temperature, the measured ice concentrations diverge from the predicted INPs by 1 to 3 orders of magni- tude, suggesting that secondary ice production is becoming increasingly dominant.

Below $-9{ }^{\circ} \mathrm{C}$, where secondary ice production is likely to be less significant, Listowski and Lachlan-Cope (2017) found that the number of INPs predicted by DeMott et al. (2010) gave better agreement with observed ice concentrations over the Antarctic Peninsula compared to INP parameterisations that only use the ambient temperature as input. For MAC, each in-cloud data point was compared with the closest (in time) out-of-cloud aerosol measurement ( 1 min average, $\mathrm{RH}<90 \%$ ). Data points were excluded from the comparison if no out-of-cloud aerosol measurements were made within $10 \mathrm{~min}$ of the in-cloud measurement. No clear relationship was found between the local aerosol concentrations and the ice concentrations $\left(R^{2}=0.02\right.$ for the above-cloud aerosol in the size range 0.5 to $1.6 \mu \mathrm{m}$ ). During MAC, the majority of cloud measurements showed no ice (see Fig. 2), suggesting that the Antarctic is a very low INP environment. As a result, all conventional INP schemes will likely overestimate the true concentrations.

\subsection{Air mass history}

The sampled air masses were classified using the NAME dispersion model based on their time spent over different geographic regions (see Sect. 2.4). Figure 12 shows vertical profiles of the aerosol from the CAS $(0.5$ to $1.5 \mu \mathrm{m}$, relative humidity $<90 \%)$ when there was high $(>50 \%$, red markers) and low ( $<50 \%$, blue markers) surface influence from the Southern Ocean, the sea ice and the Antarctic continent. There is a broad trend of higher aerosol concentra- 
(a)

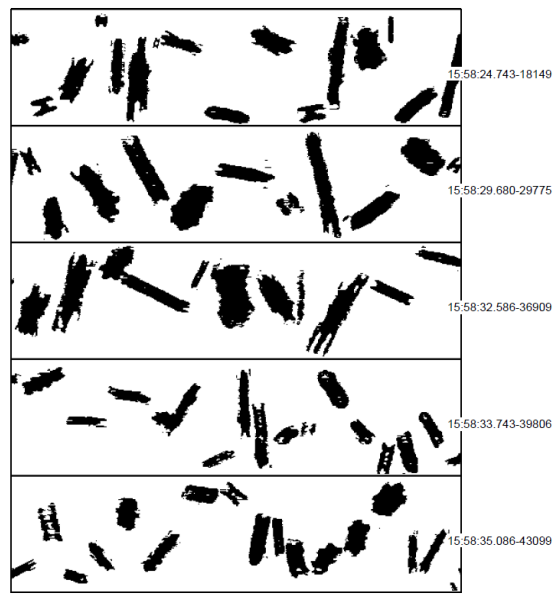

(b)

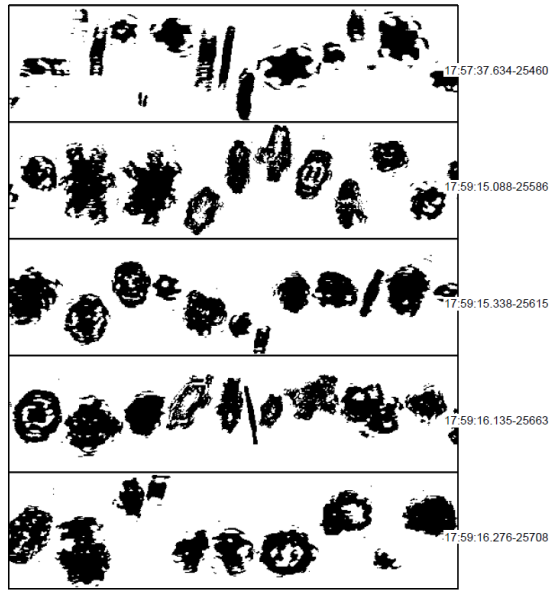

(c)

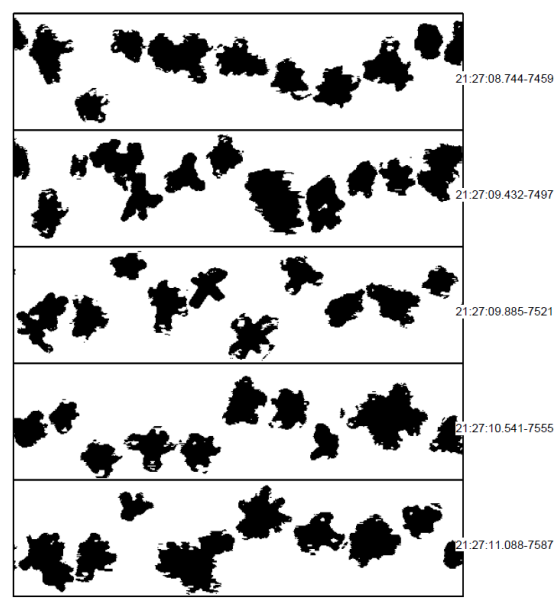

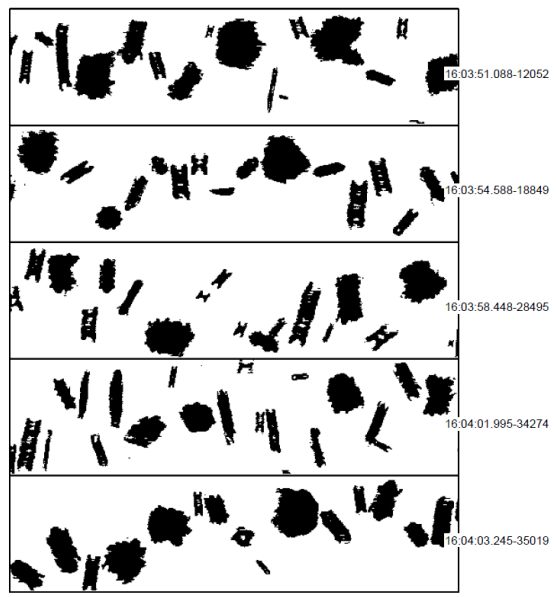
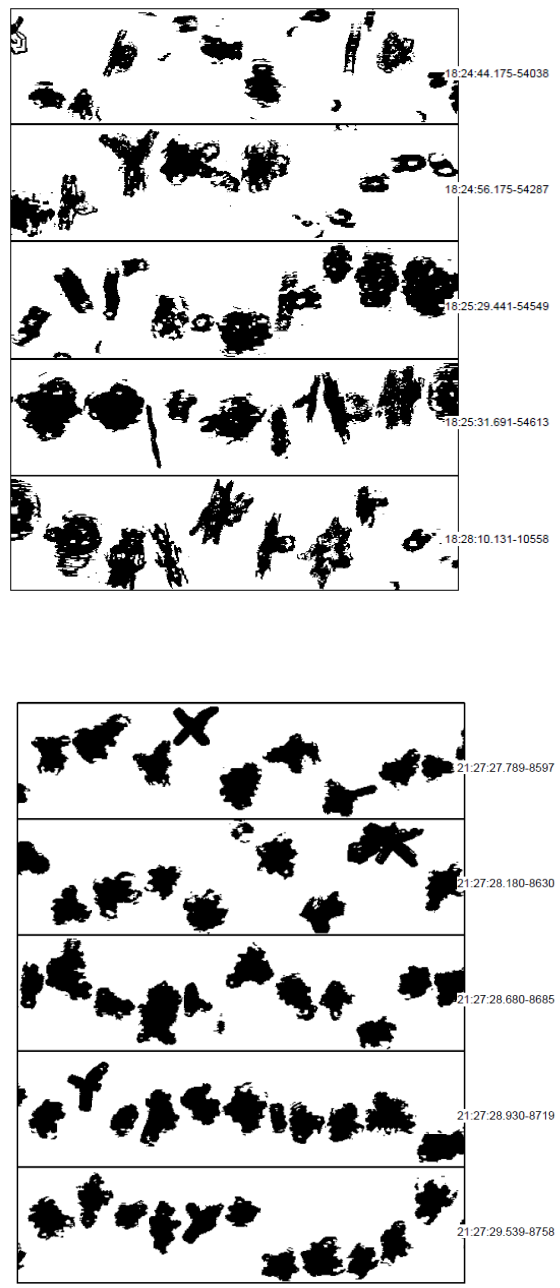

Figure 8. (a) 2DS images of highly irregular particles during a constant altitude run at $-5{ }^{\circ} \mathrm{C}(400 \mathrm{~m})$ during Flight 218 . The times given are for the first crystal on each strip. The height of each strip corresponds to the 2DS array width of $1280 \mu$ m. (b) Similar images for a constant altitude run at $-15^{\circ} \mathrm{C}$ during Flight 233 and (c) $-20^{\circ} \mathrm{C}$ during Flight 226. 

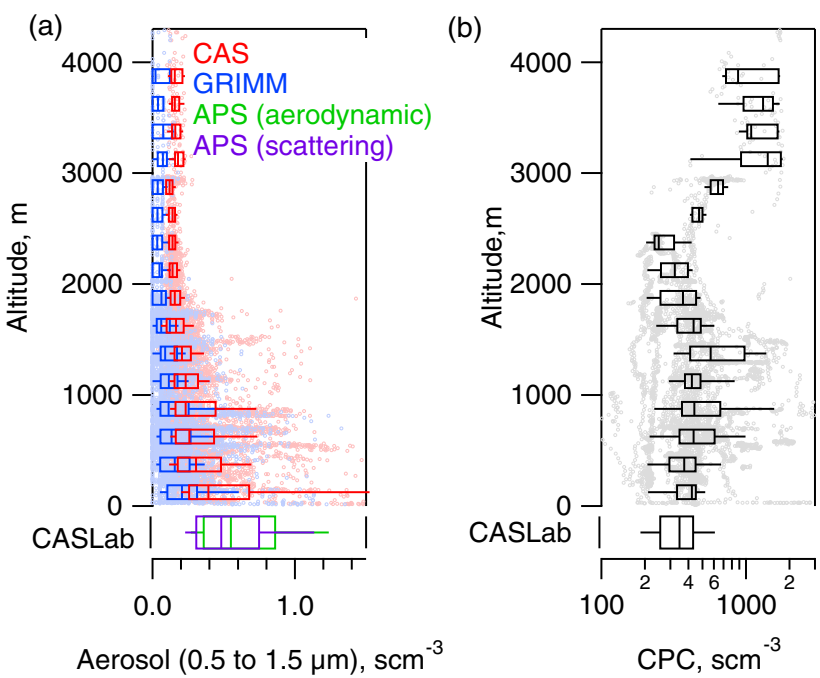

Figure 9. Aircraft clear sky aerosol concentrations $\left(\mathrm{scm}^{-3}\right)$ altitude profiles. Data are from (a) CAS and GRIMM instruments. Surface concentrations from CASLab are shown for comparison, from the APS; green - aerodynamic particle size concentrations; purple - scattering cross-section-derived particle size concentration measurements; (b) total fine aerosol concentration profiles, from CPCs on the aircraft and at the CASLab $(D>10 \mathrm{~nm})$.

tions over this size range with greater contributions from the ocean and sea ice, indicating significant emissions of seasalt/sulfate aerosol. Concentrations decrease with increased contributions from the continent, indicating a lack of sources in this region. These relationships are more distinct when the aircraft was sampling at low altitude; above approximately $1000 \mathrm{~m}$, the concentrations are less dependent on air mass origin due to their lower surface influence. This analysis was repeated using total aerosol concentrations from the CPC (Fig. 14). Similar to the CAS, higher concentrations were observed when there was greater influence from the Southern Ocean, with the differences again most distinct for the low altitude measurements. However, CPC concentrations are found to be less dependent on the influence of the sea ice and the Antarctic continent.

Compared to the aerosol measurements, the concentrations of cloud droplets and 2DS irregular particles are found to be less dependent on air mass history. Figure 13 shows these variables as a function of the relative surface influence from the Southern Ocean, sea ice and the Antarctic continent. The concentration of ice in the clouds is found to decrease for air masses with increasing influence from the ocean. However, due to ice in the clouds being relatively infrequently observed, the significance of this relationship cannot be determined. The effects of air mass history cannot easily be deconvolved from differences in sampling strategy or cloud properties (e.g. humidity, temperature, dynamics and secondary ice production). The strongest relationship between aerosols and air mass history is for particles 0.5 to $1.5 \mu \mathrm{m}$; this is only a small proportion of the total $\mathrm{CCN}$. The $\mathrm{CPC}$ provides a measurement of the total aerosol concentration, which will include the $\mathrm{CCN}$ but also particles too small to be effective $\mathrm{CCN}$. Also, given that the majority of measurements were conducted over broken sea ice, it may be that the $\mathrm{CCN}$ origin may be more local and not show up in the far field trajectories.

\section{Discussion}

This section summarises the observations presented in the paper and discusses the important microphysical processes. The cloud types were generally stratus, with both single and multiple layers, predominantly between -20 and $-3{ }^{\circ} \mathrm{C}$. These were dominated by supercooled liquid drops, with a median concentration of $113 \mathrm{~cm}^{-3}$. Droplet concentrations were relatively consistent during the campaign with an interquartile range of $86 \mathrm{~cm}^{-3}$. The exceptions to this were when the droplets were depleted by high ice concentrations and also during Flight 217 where anomalously high droplet concentrations were observed, which was associated with an enhanced aerosol layer below the cloud. Similar to Arctic layer clouds (McFarquhar et al., 2007), liquid water content and cloud droplet effective radius both increased with distance from cloud base likely due to condensational growth. Collision coalescence may also have contributed to this increase in effective radius. However, droplet number concentration was relatively invariant to position within the cloud.

Ice in the clouds exhibited a high degree of variability, occurring in small patches. Constant altitude runs by the aircraft through clouds at slightly supercooled temperatures $\left(>-10^{\circ} \mathrm{C}\right)$ showed ice-free regions with patches of high ice concentrations $\left(>1 \mathrm{~L}^{-1}\right)$. This variability is shown to exist over small spatial scales and may be a consequence of very low INP concentrations, where secondary processes may significantly amplify small differences in INP concentrations. This makes predicting in detail where ice will form in a given cloud extremely challenging. A detailed understanding of where the first ice will occur and also the conditions required for secondary production are needed. Here, we examine this variability and discuss some of the potential controlling factors.

\subsection{First ice}

First, we examine the nature and sources of the INPs. Global primary ice nucleation below approximately $-15^{\circ} \mathrm{C}$ is thought to be dominated by soot and mineral dusts (Möhler et al., 2006; Murray et al., 2012; Niemand et al., 2012). However, this is colder than the cloud top temperatures generally observed during MAC. Biological species (pollen, bacteria, fungal spores and plankton) are the only INPs that are known to be active at temperatures higher than approximately $-15^{\circ} \mathrm{C}$ (Alpert et al., 2011; Murray et al., 2012; Wil- 


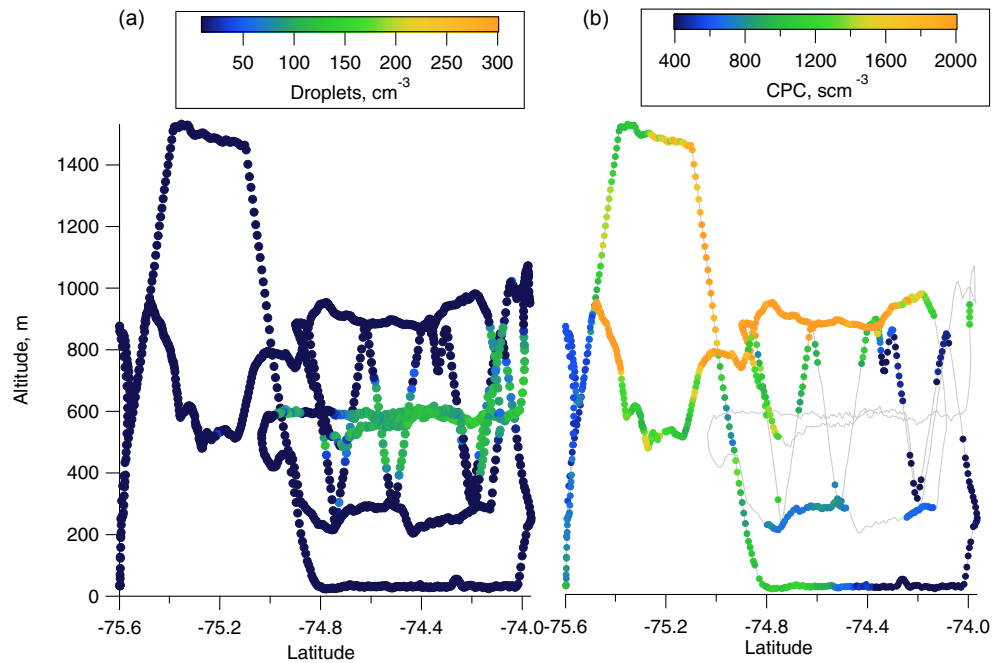

Figure 10. Latitudinal cross sections of Flight 219 coloured by droplet concentration (a) and total aerosol concentrations out of cloud (b). Grey lines shows the flight track. These show a layer of high aerosol concentrations above the cloud top.

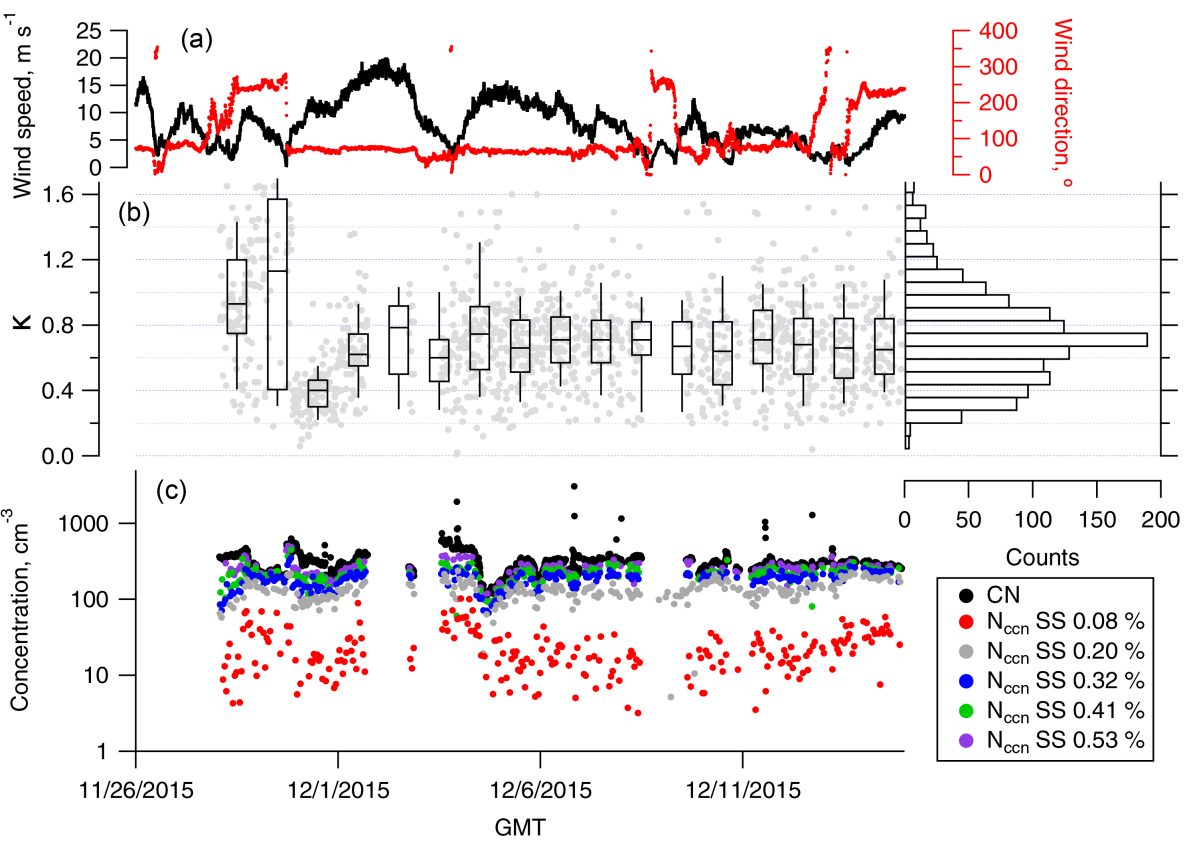

Figure 11. Panel (a) shows the time series of wind speed (black line) and direction (red markers) at the CASLab. Panel (b) shows the time series of the hygroscopicity parameter $\kappa$. The box-and-whisker plots summarise the variability in $\kappa$ for each day, while the right panel shows a histogram of $\kappa$ for the whole measurement period. Panel (c) shows the total condensation nuclei concentration ( $30 \mathrm{to} 500 \mathrm{~nm}$, black dots) and the CCN concentrations at five different supersaturations (SSs, coloured dots from 0.08 to $0.53 \%$ ). Dates are indicated in mm/dd/yyyy format.

son et al., 2015). Bioaerosol measurements at the CASLab show episodic high concentrations up to several particles per litre. This temporal variability in bioaerosol may be analogous to the spatial variability of the ice crystals observed in the clouds. Source apportionment of the bioaerosol at Halley is uncertain with the available dataset but may include contributions from (1) the resuspension of material from the local ice and snow surface, (2) coastal ice margin zones in Halley Bay where bird colonies are present and (3) long-range transport. The bioaerosol measurements will be presented and discussed in detail in a separate paper.

It is possible that the cloud layers sampled in MAC are seeded by precipitation from higher layers where the temperatures are low enough for dust to be active as an INP. Dur- 
(a)
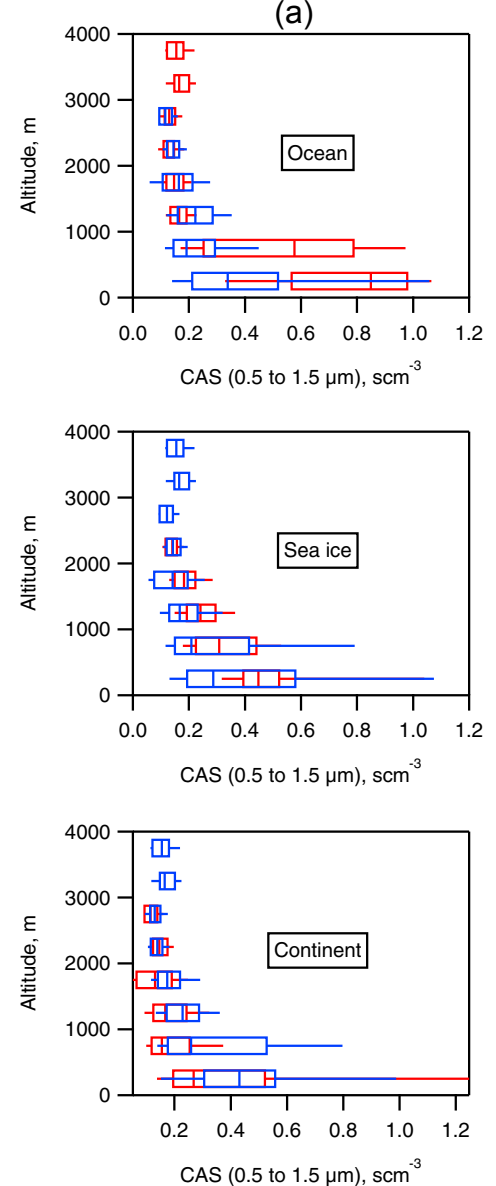

(b)
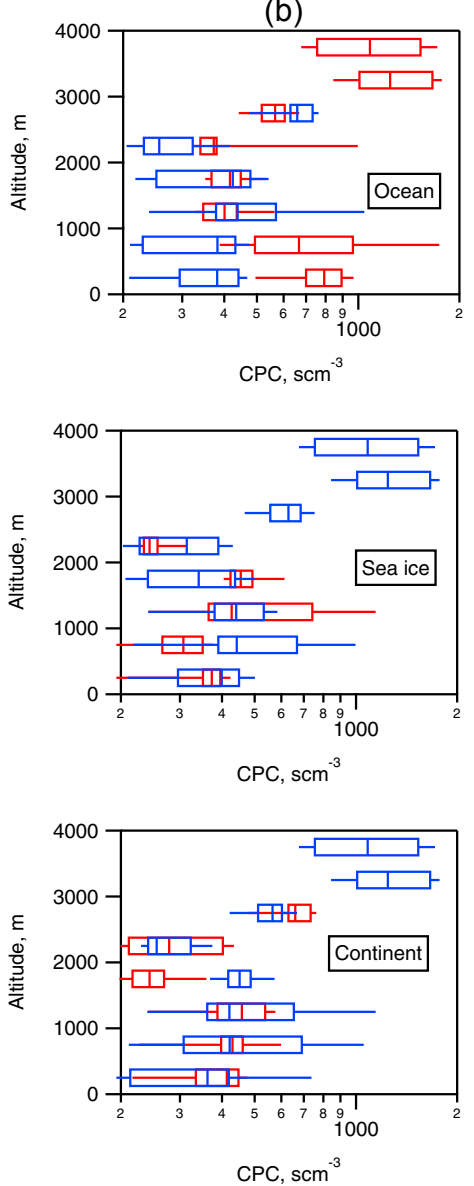

Low contribution

High contribution

Figure 12. Altitude profiles of CAS aerosol over the size range 0.5 to $1.5 \mu \mathrm{m}$ (a) and total aerosol greater than $10 \mathrm{~nm}$ from the CPC (b). The measurements have been partitioned into periods when the air mass had high (red) and low (blue) contributions from different the Southern ocean (top panels), sea ice (middle panels) and the Antarctic continent (bottom panels; see text for details).

ing MAC, the flights were designed so that measurements were performed between cloud layers to determine whether ice seeding from the upper layers was occurring. The frontal cloud sampled in Flight 224 showed extensive ice precipitating between cloud layers, and the cloud top temperature (below $-20^{\circ} \mathrm{C}$ ) was sufficiently low for dust to be a potential source of ice nuclei. The stratus clouds sampled during MAC were not found to be seeded by higher layers at low enough temperature for any dust to be active as an INP. Furthermore, single layer clouds such as those sampled in Flights 219 and 227 still showed the patchy ice behaviour.

Detailed measurements of aerosol composition were not available on the aircraft. No clear relationship could be identified between the local aerosol concentrations (both above and below cloud) and the presence of ice in the clouds. However, only a small proportion of the total aerosol population is expected to be INPs. Below approximately $1000 \mathrm{~m}$ (where most of MAC measurements were performed), there is a broad trend of ice being more frequent with decreasing altitude. A similar relationship is observed for the concentration of particles between 0.5 and $1.6 \mu \mathrm{m}$ (Fig. 9). However, this may in part be due to secondary ice production being efficient at these relatively high temperatures. Jackson et al. (2012) found a correlation $(R=0.69)$ between the above-cloud aerosol $(0.1<D<3 \mu \mathrm{m})$ and ice concentrations in Arctic stratocumulus clouds. However, these clouds were generally at lower temperatures (cloud top temperature $<-10^{\circ} \mathrm{C}$ ) than those during MAC and as a result are likely to have a higher proportion of primary ice production.

The surface may also be an ice crystal source either through blowing snow (Ardon-Dryer et al., 2011) or frost flowers (Gallet et al., 2014; Lloyd et al., 2015b). These will be most important for clouds in contact with the surface (Vali et al., 2012) but may also be relevant for low clouds when the 

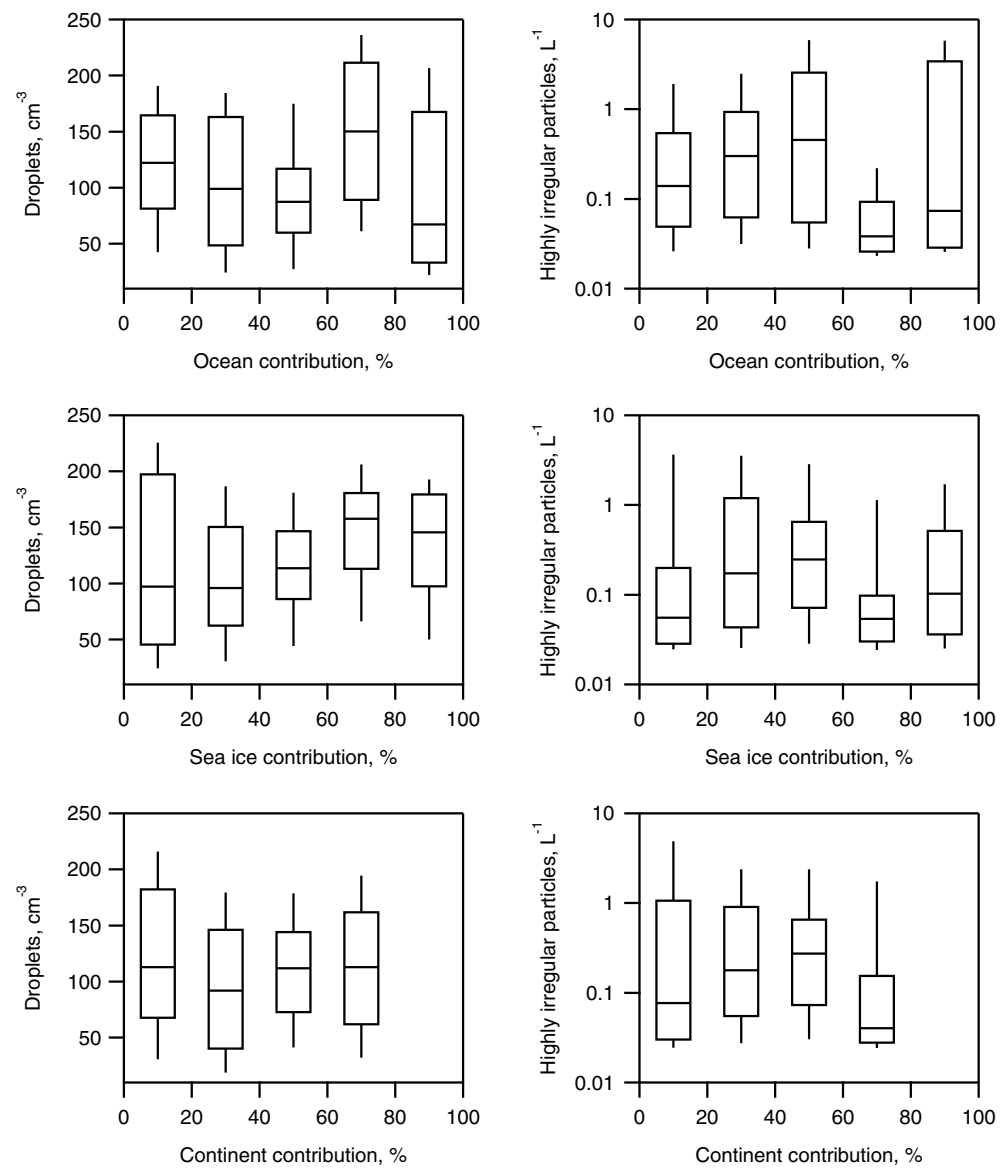

Figure 13. The concentration of cloud droplets and 2DS highly irregular particles as a function of the air mass contribution from the Southern Ocean, sea ice and the continent (see text for details). Boxes give the 25th and 75th and the whiskers mark the 10th and 90th percentiles for each regional contribution bin.

humidity is sufficiently high that the crystals do not evaporate whilst being transported to the cloud base (Geerts et al., 2015). Space-borne lidar measurements of blowing snow over Antarctica found the thickness of these layers ranging between their detection limit $(30 \mathrm{~m})$ up to $1000 \mathrm{~m}$, with an average thickness of $100 \mathrm{~m}$. Approximately $71 \%$ of these layers were less than $100 \mathrm{~m}$ thick and $25 \%$ were between 100 and $300 \mathrm{~m}$ thick (Palm et al., 2011). Similarly, lidar measurements at the South Pole found that layers were generally less than $400 \mathrm{~m}$ thick (63\%) but could be up to $1000 \mathrm{~m}$ thick. Blowing snow is almost always constrained to the planetary boundary layer (Mahesh, 2003). The lofting of snow is complex; it is dependent on a range of variables, including the snow type and surface meteorology (e.g. wind speed, turbulent mixing, temperature and humidity). A threshold wind speed of 7 to $10 \mathrm{~m} \mathrm{~s}^{-1}$ is typically required (Déry and Yau, 1999). However, smaller crystals may show substantial fluxes at lower wind speeds. Aerosol fluxes from evaporated frost flowers have been estimated at $10^{-6} \mathrm{~m}^{-2} \mathrm{~s}^{-1}$ at wind speeds as low as $1 \mathrm{~m} \mathrm{~s}^{-1}$ (Xu et al., 2013).

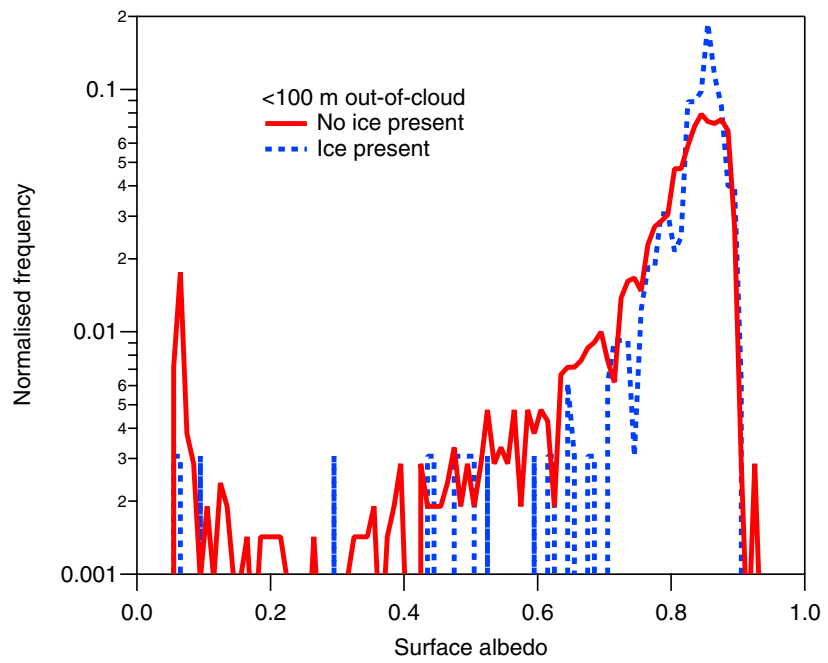

Figure 14. Frequency plots of the surface albedo for of out-of-cloud measurements (below $100 \mathrm{~m}$ ) when there was (blue line) and was not (red line) ice detected. 
Evaluating the impact of these mechanisms during MAC is challenging since most of the in-cloud sampling was performed over snow-covered sea ice, making it difficult to attribute local differences in the microphysics to the surface type. Figure 14 shows histograms of the surface albedo for out-of-cloud measurements (below $100 \mathrm{~m}$ ) when there was (blue line) and was not (red line) ice observed. Here, the surface albedo is used as a proxy for the surface type, since values near 0 correspond to overflying open water and the values near 1 correspond to a snow-/ice-covered surface. Figure 14 suggests that ice measured by the aircraft while out cloud (below $100 \mathrm{~m}$ ) almost exclusively occurred when overflying a snow-/ice-covered surface, implying a link between the surface type and the presence of ice in the clouds. The ice measured on the aircraft when it was out of the cloud could either have originated from the surface or precipitated from clouds above. However, it should be noted that very few measurements were made over open water regions.

Flight 218 (Fig. 7) is one case where the first ice development may be due to surface ice crystals. During this flight, ice was observed precipitating below cloud base. The majority of this ice precipitation was detected when flying over snowcovered sea ice rather than open water. Given the relatively low cloud base $(300 \mathrm{~m})$, strong surface horizontal winds (5 to $10 \mathrm{~m} \mathrm{~s}^{-1}$ ) and a relative humidity approaching $100 \%$, it is plausible that ice from the surface (e.g. from blowing snow) could mix up to cloud base, thus providing the first ice to the cloud. The sublimation rate of an ice crystal is largely dependent on the humidity. A $100 \mu \mathrm{m}$ ice crystal at $0^{\circ} \mathrm{C}$ will have a lifetime of the order $100 \mathrm{~s}$ at a relative humidity of $80 \%$. At relative humilities of 90 and $95 \%$, the lifetime can be over 200 and $400 \mathrm{~s}$, respectively (Thorpe and Mason, 1966). The ice crystals below cloud had similar habits to those observed in the cloud (a mixture of columns and rimed crystals), indicating they had not originated from the surface. However, only low concentrations of primary ice from the surface are needed if the ice is then able to multiply within the cloud due to secondary processes (Crawford et al., 2012).

\subsection{Secondary ice}

Previous ice crystal observations over the Antarctic Peninsula show a similar behaviour to those during MAC, with a peak in ice concentrations $\left(>1 \mathrm{~L}^{-1}\right)$ at approximately $-5^{\circ} \mathrm{C}$. Grosvenor et al. (2012) and Lachlan-Cope et al. (2016) attribute this to secondary ice production through the Hallett-Mossop process, where ice splinters are produced when a droplet freezes subsequent to colliding with an ice crystal (riming) (Hallett and Mossop, 1974). This can lead to rapid ice multiplication as the splinters freeze further drops, resulting in more splinters. Laboratory experiments suggest that this process is efficient over a narrow temperature range $\left(-8\right.$ to $\left.-3{ }^{\circ} \mathrm{C}\right)$ with a peak at $-5^{\circ} \mathrm{C}$ (Mossop, 1976). Images from the 2DS probe at temperatures higher than $-10^{\circ} \mathrm{C}$ generally show rimed crystals and small columns (Fig. 10a). These habits are generally observed when the Hallett-Mossop production mechanism is thought to be occurring (Crosier et al., 2011; Lloyd et al., 2015a).

A number of other secondary ice mechanisms have previously been identified; these include large drops producing ice splinters when they freeze (Rangno and Hobbs, 2001; Lawson et al., 2015) and the break-up of ice crystals, generally either fragile dendrites due to sublimation, turbulence (Bacon et al., 1998) or because of collisions between crystals (Yano and Phillips, 2011). However, all these processes have generally only been observed to be efficient at temperatures lower than approximately $-10^{\circ} \mathrm{C}$, which is lower than the temperature of the majority of clouds sampled during MAC. Taylor et al. (2015) suggest that the drop-freezing secondary ice production, identified by Lawson et al. (2015), may have occurred at temperatures higher than $-10^{\circ} \mathrm{C}$ in their measurements of cumulus clouds. However, they were not able to deconvolve its effects from the Hallett-Mossop mechanism. We have not performed automatic habit recognition on the 2DS images taken during MAC; however, inspecting the images "by eye" suggests that the drop-shattering events observed by Lawson et al. (2015) were not common during MAC.

The exact requirements for secondary ice production through Hallett-Mossop are still uncertain. It is thought that only a small of amount of primary ice is needed for it to be initiated, and recent model studies suggest this could be as low as $0.01 \mathrm{~L}^{-1}$ (Crawford et al., 2012; Huang et al., 2017). Laboratory experiments suggest that production rates are proportional to the accumulation of large drops $(>24 \mu \mathrm{m})$ (Mossop and Hallett, 1974; Mossop, 1985). However, more recent field measurements found that estimated crystal production rates gave better agreement with observed ice concentrations if this constraint on drop diameter was removed (Crosier et al., 2011). Observations of Arctic mixed-phase clouds found that the presence of precipitating ice particles $(>400 \mu \mathrm{m})$ was correlated with the number of large drops (> $30 \mu \mathrm{m})$; however, the precise nucleation mechanism through which this occurred was uncertain (Lance et al., 2011). During MAC, both the analysis of individual case studies and the statistics for the whole campaign do not suggest that the concentration of large drops and ice crystals was related. However, any simple relationship is likely to be complicated as ice crystal growth will deplete the drops through riming and the Wegener-Bergeron-Findeisen process. This is shown in Figs. 5 and $6 \mathrm{~b}$ where the highest ice concentrations correspond to relatively low droplet concentrations.

Flights 226, 227 and 228 involved sequential vertical profiles to examine the dependency of ice on the clouds' vertical structure. No link was identified between the presence of ice in the vertical profile and local variations in cloud top temperature. However, since the first ice occurs over small spatial scales, any relationship may be obscured by the aircraft's horizontal motion whilst changing altitude. As a re- 
sult, the precise cloud top temperature, and its variability, directly above the glaciated regions of the clouds is not known.

\section{Conclusions}

Understanding the clouds in the Antarctic is essential for making accurate predictions of future climate change. We have reported unique observations of cloud and aerosol properties over coastal Antarctica and the Weddell Sea. The aerosol was predominantly hygroscopic in nature, with $\kappa$ being consistent with previous measurements and model predictions for remote locations dominated by marine emissions. The concentration of large aerosols $(0.5$ to $1.6 \mu \mathrm{m})$ decreased with altitude, as would be expected, through seasalt/sulfate aerosol being rapidly removed by cloud processing or sedimentation. Higher aerosol concentrations were observed in air masses that travelled over the Southern Ocean/sea ice compared to those from the main Antarctic continent.

In contrast to the aerosol concentrations, the droplet and ice concentrations showed minimal dependence on air mass origin; it may be that the $\mathrm{CCN}$ origin may be more local and not show up in the far field trajectories. The cloud types were generally stratus, with both single and multiple layers, at temperatures between -20 and $-3{ }^{\circ} \mathrm{C}$. These were dominated by supercooled liquid drops, with a median concentration of $113 \mathrm{~cm}^{-3}$. Droplet concentrations were relatively consistent throughout the campaign with an interquartile range of $86 \mathrm{~cm}^{-3}$. The exceptions to this were cases when the concentrations became depleted by high ice concentrations and also during Flight 217, when anomalously high droplet concentrations were observed; this was associated with an enhanced aerosol layer below the cloud layer. Both liquid water content and droplet effective radius increased near cloud top.

Ice in the clouds exhibited a high degree of inhomogeneity occurring in small patches. Below approximately $1000 \mathrm{~m}$, ice was more frequent at higher temperatures; however, even within the -8 to $-3{ }^{\circ} \mathrm{C}$ temperature range where HallettMossop secondary production is most active, the clouds were predominantly liquid. When ice was present within the temperature range -8 to $-3{ }^{\circ} \mathrm{C}$, it seems likely that secondary ice production, through the Hallett-Mossop process, resulted in concentrations that were 1 to 3 orders of magnitude higher than the number of INPs predicted by conventional primary ice nucleation schemes. The source of first ice in the clouds is currently uncertain. First ice in the clouds often occurs at temperatures above $-10^{\circ} \mathrm{C}$; this may be due to the presence of biogenic particles that are active INPs at these temperatures, or alternatively (or indeed simultaneously) ice from the surface (e.g. blowing snow or frost flowers) could be lofted into the clouds.

This paper has presented the most detailed in situ observations of coastal Antarctic clouds and their surrounding aerosol properties to date. Upcoming studies will use the MAC observations to test and improve the representation of Antarctic clouds in numerical weather/climate models in this particularly important region.

Data availability. The data are being prepared for inclusion in the Polar Data Centre and will be available soon.

\section{The Supplement related to this article is available online at https://doi.org/10.5194/acp-17-13049-2017- supplement.}

Competing interests. The authors declare that they have no conflict of interest.

Acknowledgements. The authors would like to thank Vicky Auld, Neil Brough and all the BAS staff who helped in the Antarctic. We are grateful to Gillian Young for her assistance with the ERA-Interim reanalysis data. The MAC project was funded by the UK Natural Environment Research Council (grant no. $\mathrm{NE} / \mathrm{K} 01482 \mathrm{X} / 1$ ).

Edited by: Veli-Matti Kerminen

Reviewed by: two anonymous referees

\section{References}

Alpert, P. A., Aller, J. Y., and Knopf, D. A.: Initiation of the ice phase by marine biogenic surfaces in supersaturated gas and supercooled aqueous phases, Phys. Chem. Chem. Phys., 13, 19882, https://doi.org/10.1039/c1cp21844a, 2011.

Amato, P., Joly, M., Schaupp, C., Attard, E., Möhler, O., Morris, C. E., Brunet, Y., and Delort, A.-M.: Survival and ice nucleation activity of bacteria as aerosols in a cloud simulation chamber, Atmos. Chem. Phys., 15, 6455-6465, https://doi.org/10.5194/acp15-6455-2015, 2015.

Andreae, M. O. and Rosenfeld, D.: Aerosol-cloudprecipitation interactions. Part 1. The nature and sources of cloud-active aerosols, Earth-Sci. Rev., 89, 13-41, https://doi.org/10.1016/j.earscirev.2008.03.001, 2008.

Ardon-Dryer, K., Levin, Z., and Lawson, R. P.: Characteristics of immersion freezing nuclei at the South Pole station in Antarctica, Atmos. Chem. Phys., 11, 4015-4024, https://doi.org/10.5194/acp-11-4015-2011, 2011.

Asmi, E., Frey, A., Virkkula, A., Ehn, M., Manninen, H. E., Timonen, H., Tolonen-Kivimäki, O., Aurela, M., Hillamo, R., and Kulmala, M.: Hygroscopicity and chemical composition of Antarctic sub-micrometre aerosol particles and observations of new particle formation, Atmos. Chem. Phys., 10, 4253-4271, https://doi.org/10.5194/acp-10-4253-2010, 2010.

Bacon, N. J., Swanson, B. D., Baker, M. B., and Davis, E. J.: Breakup of levitated frost particles, J. Geophys. Res.-Atmos., 103, 13763-13775, https://doi.org/10.1029/98JD01162, 1998. 
Baumgardner, D., Jonsson, H., Dawson, W., O'Connor, D., and Newton, R.: The cloud, aerosol and precipitation spectrometer: a new instrument for cloud investigations, Atmos. Res., 59-60, 251-264, https://doi.org/10.1016/S0169-8095(01)001193, 2001.

Baumgardner, D., Newton, R., Krämer, M., Meyer, J., Beyer, A., Wendisch, M., and Vochezer, P.: The cloud particle spectrometer with polarization detection (CPSPD): a next generation open-path cloud probe for distinguishing liquid cloud droplets from ice crystals, Atmos. Res., 142, 2-14, https://doi.org/10.1016/j.atmosres.2013.12.010, 2014.

Bigg, E. K.: Long-term trends in ice nucleus concentrations, Atmos. Res., 25, 409-415, https://doi.org/10.1016/01698095(90)90025-8, 1990.

Bodas-Salcedo, A., Williams, K. D., Field, P. R., and Lock, A. P.: The surface downwelling solar radiation surplus over the southern ocean in the met office model: the role of midlatitude cyclone clouds, J. Climate, 25, 7467-7486, https://doi.org/10.1175/JCLID-11-00702.1, 2012.

Bodas-Salcedo, A., Hill, P. G., Furtado, K., Karmalkar, A., Williams, K. D., Field, P. R., Manners, J. C., Hyder, P., and Kato, S.: Large contribution of supercooled liquid clouds to the solar radiation budget of the Southern Ocean, J. Climate, 29, 4213-4228, 2016.

Bromwich, D. H., Nicolas, J. P., Hines, K. M., Kay, J. E., Key, E. L., Lazzara, M. A., Lubin, D., McFarquhar, G. M., Gorodetskaya, I. V, Grosvenor, D. P., Lachlan-Cope, T., and Van Lipzig, N. P. M.: Tropospheric clouds in Antarctica, Rev. Geophys., 50, 1-40, https://doi.org/10.1029/2011RG000363, 2012.

Bromwich, D. H., Otieno, F. O., Hines, K. M., Manning, K. W., and Shilo, E.: Comprehensive evaluation of polar weather research and forecasting model performance in the antarctic, J. Geophys. Res.-Atmos., 118, 274-292, https://doi.org/10.1029/2012JD018139, 2013.

Brown, P. and Francis, P.: Improved measurements of the ice water content in cirrus using a total-water probe, J. Atmos. Ocean., 12, 410-414, https://doi.org/10.1175/15200426(1995)012<0410:IMOTIW>2.0.CO;2, 1995.

Christner, B. C., Morris, C. E., Foreman, C. M., Cai, R., and Sands, D. C.: Ubiquity of biological ice nucleators in snowfall, Science, 319, 1214, https://doi.org/10.1126/science.1149757, 2008.

Cooper, W. A.: Ice initiation in natural clouds, Meteor. Mon., 21, 29-32, https://doi.org/10.1175/0065-9401-21.43.29, 1986.

Crawford, I., Bower, K. N., Choularton, T. W., Dearden, C., Crosier, J., Westbrook, C., Capes, G., Coe, H., Connolly, P. J., Dorsey, J. R., Gallagher, M. W., Williams, P., Trembath, J., Cui, Z., and Blyth, A.: Ice formation and development in aged, wintertime cumulus over the UK: observations and modelling, Atmos. Chem. Phys., 12, 4963-4985, https://doi.org/10.5194/acp12-4963-2012, 2012.

Crawford, I., Gallagher, M. W., Bower, K. N., Choularton, T. W., Flynn, M. J., Ruske, S., Listowski, C., Brough, N., LachlanCope, T., Fleming, Z. L., Foot, V. E., and Stanley, W. R.: Real Time Detection of Airborne Bioparticles in Antarctica, Atmos. Chem. Phys. Discuss., https://doi.org/10.5194/acp-2017-421, in review, 2017.

Crosier, J., Bower, K. N., Choularton, T. W., Westbrook, C. D., Connolly, P. J., Cui, Z. Q., Crawford, I. P., Capes, G. L., Coe, H.,
Dorsey, J. R., Williams, P. I., Illingworth, A. J., Gallagher, M. W., and Blyth, A. M.: Observations of ice multiplication in a weakly convective cell embedded in supercooled mid-level stratus, Atmos. Chem. Phys., 11, 257-273, https://doi.org/10.5194/acp-11257-2011, 2011.

Dee, D. P., Uppala, S. M., Simmons, A. J., Berrisford, P., Poli, P., Kobayashi, S., Andrae, U., Balmaseda, M. A., Balsamo, G., Bauer, P., Bechtold, P., Beljaars, A. C. M., van de Berg, L., Bidlot, J., Bormann, N., Delsol, C., Dragani, R., Fuentes, M., Geer, A. J., Haimberger, L., Healy, S. B., Hersbach, H., Holm, E. V., Isaksen, L., Kållberg, P., Köhler, M., Matricardi, M., McNally, A. P., Monge-Sanz, B. M., Morcrette, J.-J., Park, B.K., Peubey, C., de Rosnay, P., Tavolato, C., Thepaut, J.-N., and Vitart, F.: The ERA-Interim reanalysis: configuration and performance of the data assimilation system, Q. J. Roy. Meteorol. Soc., 137, 553-597, 2011.

DeMott, P. J., Prenni, a J., Liu, X., Kreidenweis, S. M., Petters, M. D., Twohy, C. H., Richardson, M. S., Eidhammer, T., and Rogers, D. C.: Predicting global atmospheric ice nuclei distributions and their impacts on climate, P. Natl. Acad. Sci. USA, 107 11217-11222, https://doi.org/10.1073/pnas.0910818107, 2010.

DeMott, P. J., Hill, T. C. J., McCluskey, C. S., Prather, K. A., Collins, D. B., Sullivan, R. C., Ruppel, M. J., Mason, R. H., Irish, V. E., Lee, T., Hwang, C. Y., Rhee, T. S., Snider, J. R., McMeeking, G. R., Dhaniyala, S., Lewis, E. R., Wentzell, J. J. B., Abbatt, J., Lee, C., Sultana, C. M., Ault, A. P., Axson, J. L., Diaz Martinez, M., Venero, I., Santos-Figueroa, G., Stokes, M. D., Deane, G. B., Mayol-Bracero, O. L., Grassian, V. H., Bertram, T. H., Bertram, A. K., Moffett, B. F., and Franc, G. D.: Sea spray aerosol as a unique source of ice nucleating particles, P. Natl. Acad. Sci. USA, 113, 5797-5803, https://doi.org/10.1073/pnas.1514034112, 2015.

Déry, S. J. and Yau, M. K.: A climatology of adverse winter-type weather events, J. Geophys. Res.-Atmos., 104, 16657-16672, https://doi.org/10.1029/1999JD900158, 1999.

Fleming, Z. L., Monks, P. S., and Manning, A. J.: Review: Untangling the influence of air-mass history in interpreting observed atmospheric composition, Atmos. Res., 104-105, 1-39, https://doi.org/10.1016/j.atmosres.2011.09.009, 2012.

Gallet, J.-C., Domine, F., Savarino, J., Dumont, M., and Brun, E.: The growth of sublimation crystals and surface hoar on the Antarctic plateau, The Cryosphere, 8, 1205-1215, https://doi.org/10.5194/tc-8-1205-2014, 2014.

Geerts, B., Pokharel, B., and Kristovich, D. A. R.: Blowing snow as a natural glaciogenic cloud seeding mechanism, Mon Weather Rev., 143, 5017-5033, https://doi.org/10.1175/MWRD-15-0241.1, 2015.

Gibson, J. A. E., Garrick, R. C., Burton, H. R., and McTaggart, A. R.: Dimethylsulfide and the alga Phaeocystis pouchetii in antarctic coastal waters, Mar. Biol., 104, 339-346, https://doi.org/10.1007/BF01313276, 1990.

Giordano, M. R., Kalnajs, L. E., Avery, A., Goetz, J. D., Davis, S. M., and DeCarlo, P. F.: A missing source of aerosols in Antarctica - beyond long-range transport, phytoplankton, and photochemistry, Atmos. Chem. Phys., 17, 1-20, https://doi.org/10.5194/acp17-1-2017, 2017.

Good, N., Coe, H., and McFiggans, G.: Instrumentational operation and analytical methodology for the reconciliation of aerosol water uptake under sub- and supersaturated conditions, Atmos. 
Meas. Tech., 3, 1241-1254, https://doi.org/10.5194/amt-3-12412010, 2010.

Grosvenor, D. P., Choularton, T. W., Lachlan-Cope, T., Gallagher, M. W., Crosier, J., Bower, K. N., Ladkin, R. S., and Dorsey, J. R.: In-situ aircraft observations of ice concentrations within clouds over the Antarctic Peninsula and Larsen Ice Shelf, Atmos. Chem. Phys., 12, 11275-11294, https://doi.org/10.5194/acp-12-112752012, 2012.

Hallett, J. and Mossop, S. C. C.: Production of secondary ice particles during the riming process, Nature, 249, 26-28, https://doi.org/10.1038/249026a0, 1974.

Huang, Y., Blyth, A. M., Brown, P. R. A., Choularton, T. W., and Cui, Z.: Factors controlling secondary ice production in cumulus clouds, Q. J. Roy. Meteorol. Soc., 143, 1021-1031, https://doi.org/10.1002/qj.2987, 2017.

Jackson, R. C., McFarquhar, G. M., Korolev, A. V., Earle, M. E., Liu, P. S. K., Lawson, R. P., Brooks, S., Wolde, M., Laskin, A., and Freer, M.: The dependence of ice microphysics on aerosol concentration in arctic mixed-phase stratus clouds during ISDAC and M-PACE, J. Geophys. Res.-Atmos., 117, D15207, https://doi.org/10.1029/2012JD017668, 2012.

Jones, A. , Thomson, D., Hort, M., and Devenish, B.: The UK Met Office's next-generation atmospheric dispersion model, NAME III, in: Air Pollution Modeling and Its Application XVII, edited by: Borrego, C. and Norman, A.-L., Springer US, USA,, 580-589, 2007.

Jones, A. E., Wolff, E. W., Salmon, R. A., Bauguitte, S. J.-B., Roscoe, H. K., Anderson, P. S., Ames, D., Clemitshaw, K. C., Fleming, Z. L., Bloss, W. J., Heard, D. E., Lee, J. D., Read, K. A., Hamer, P., Shallcross, D. E., Jackson, A. V., Walker, S. L., Lewis, A. C., Mills, G. P., Plane, J. M. C., Saiz-Lopez, A., Sturges, W. T., and Worton, D. R.: Chemistry of the Antarctic Boundary Layer and the Interface with Snow: an overview of the CHABLIS campaign, Atmos. Chem. Phys., 8, 3789-3803, https://doi.org/10.5194/acp-8-3789-2008, 2008.

Junge, K. and Swanson, B. D.: High-resolution ice nucleation spectra of sea-ice bacteria: implications for cloud formation and life in frozen environments, Biogeosciences, 5, 865-873, https://doi.org/10.5194/bg-5-865-2008, 2008.

King, J. C., Lachlan-Cope, T. A., Ladkin, R. S., and Weiss, A.: Airborne measurements in the stable boundary layer over the Larsen Ice Shelf, Antarctica, Bound.-Layer Meteorol., 127, 413-428, https://doi.org/10.1007/s10546-008-9271-4, 2008.

King, J. C., Gadian, A., Kirchgaessner, A., Kuipers Munneke, P., Lachlan-Cope, T. A., Orr, A., Reijmer, C., van den Broeke, M. R., van Wessem, J. M., and Weeks, M.: Validation of the summertime surface energy budget of Larsen C Ice Shelf (Antarctica) as represented in three high-resolution atmospheric models, J. Geophys. Res.-Atmos., 120, 1335-1347, https://doi.org/10.1002/2014JD022604, 2015.

Korolev, A. V., Emery, E. F., Strapp, J. W., Cober, S. G., Isaac, G. A., Wasey, M., and Marcotte, D.: Small ice particles in tropospheric clouds: fact or artifact? Airborne icing instrumentation evaluation experiment, B. Am. Meteorol. Soc., 92, 967-973, https://doi.org/10.1175/2010BAMS3141.1, 2011.

Kumai, M.: Identification of nuclei and concentrations of chemical species in snow crystals sampled at the South Pole, J. Atmos. Sci., 33, 833-841, https://doi.org/10.1175/15200469(1976)033<0833:IONACO>2.0.CO;2, 1976.
Lachlan-Cope, T., Listowski, C., and O'Shea, S.: The microphysics of clouds over the Antarctic Peninsula - Part 1: Observations, Atmos. Chem. Phys., 16, 15605-15617, https://doi.org/10.5194/acp-16-15605-2016, 2016.

Lance, S., Brock, C. A., Rogers, D., and Gordon, J. A.: Water droplet calibration of the Cloud Droplet Probe (CDP) and in-flight performance in liquid, ice and mixed-phase clouds during ARCPAC, Atmos. Meas. Tech., 3, 1683-1706, https://doi.org/10.5194/amt-3-1683-2010, 2010.

Lance, S., Shupe, M. D., Feingold, G., Brock, C. A., Cozic, J., Holloway, J. S., Moore, R. H., Nenes, A., Schwarz, J. P., Spackman, J. R., Froyd, K. D., Murphy, D. M., Brioude, J., Cooper, O. R., Stohl, A., and Burkhart, J. F.: Cloud condensation nuclei as a modulator of ice processes in Arctic mixed-phase clouds, Atmos. Chem. Phys., 11, 8003-8015, https://doi.org/10.5194/acp11-8003-2011, 2011.

Lathem, T. L., Beyersdorf, A. J., Thornhill, K. L., Winstead, E. L., Cubison, M. J., Hecobian, A., Jimenez, J. L., Weber, R. J., Anderson, B. E., and Nenes, A.: Analysis of CCN activity of Arctic aerosol and Canadian biomass burning during summer 2008, Atmos. Chem. Phys., 13, 2735-2756, https://doi.org/10.5194/acp13-2735-2013, 2013.

Lawson, R. P. and Gettelman, A.: Impact of Antarctic mixed-phase clouds on climate, P. Natl. Acad. Sci. USA, 111, 18156-18161, https://doi.org/10.1073/pnas.1418197111, 2014.

Lawson, R. P., O'Connor, D., Zmarzly, P., Weaver, K., Baker, B., Mo, Q., and Jonsson, H.: The 2D-S (stereo) probe: design and preliminary tests of a new airborne, high-speed, high-resolution particle imaging probe, J. Atmos. Ocean. Tech., 23, 1462-1477, https://doi.org/10.1175/JTECH1927.1, 2006.

Lawson, R. P., Woods, S., and Morrison, H.: The microphysics of ice and precipitation development in tropical cumulus clouds, J. Atmos. Sci., 72, 2429-2445, https://doi.org/10.1175/JAS-D-140274.1, 2015.

Legrand, M., Yang, X., Preunkert, S., and Therys, N.: Year-round records of sea salt, gaseous, and particulate inorganic bromine in the atmospheric boundary layer at coastal (Dumont d'Urville) and central (Concordia) East Antarctic sites, J. Geophys. Res.Atmos., 121, 997-1023, https://doi.org/10.1002/2015JD024066, 2016.

Listowski, C. and Lachlan-Cope, T.: The microphysics of clouds over the Antarctic Peninsula - Part 2: modelling aspects within Polar WRF, Atmos. Chem. Phys., 17, 10195-10221, https://doi.org/10.5194/acp-17-10195-2017, 2017.

Liu, D., Quennehen, B., Darbyshire, E., Allan, J. D., Williams, P. I., Taylor, J. W., Bauguitte, S. J.-B., Flynn, M. J., Lowe, D., Gallagher, M. W., Bower, K. N., Choularton, T. W., and Coe, H.: The importance of Asia as a source of black carbon to the European Arctic during springtime 2013, Atmos. Chem. Phys., 15, 1153711555, https://doi.org/10.5194/acp-15-11537-2015, 2015.

Lloyd, G., Choularton, T. W., Bower, K. N., Crosier, J., Jones, H., Dorsey, J. R., Gallagher, M. W., Connolly, P., Kirchgaessner, A. C. R., and Lachlan-Cope, T.: Observations and comparisons of cloud microphysical properties in spring and summertime Arctic stratocumulus clouds during the ACCACIA campaign, Atmos. Chem. Phys., 15, 3719-3737, https://doi.org/10.5194/acp15-3719-2015, 2015a.

Lloyd, G., Choularton, T. W., Bower, K. N., Gallagher, M. W., Connolly, P. J., Flynn, M., Farrington, R., Crosier, J., Sch- 
lenczek, O., Fugal, J., and Henneberger, J.: The origins of ice crystals measured in mixed-phase clouds at the highalpine site Jungfraujoch, Atmos. Chem. Phys., 15, 12953-12969, https://doi.org/10.5194/acp-15-12953-2015, 2015 b.

Lubin, D., Chen, B., Bromwich, D. H., Somerville, R. C. J., Lee, W. H., and Hines, K. M.: The impact of antarctic cloud radiative properties on a GCM climate simulation, J. Climate, 11, 447-462, https://doi.org/10.1175/15200442(1998)011<0447:TIOACR>2.0.CO;2, 1998.

Mahesh, A.: Observations of blowing snow at the South Pole, J. Geophys. Res.-Atmos., 108, 1-9, https://doi.org/10.1029/2002JD003327, 2003.

Mangold, A., Delcloo, A., De Backer, H., Laffineur, Q., Herenz. P., Wex, H., Gossart, A., Souverijns, N., Gorodetskaya, I., and Van Lipzig, N.: CCN and Aerosol Properties at Princess Elisabeth Station, East Antarctica, Combined with Cloud and Precipitation Observations and Air Mass Origin, Geophysical Research Abstracts, EGU2017-18217, EGU General Assembly, Vienna, 2017.

Maslanik, J. and Stroeve, J.: Near-Real-Time DMSP SSMIS Daily Polar Gridded Sea Ice Concentrations, Version 1, NASA National Snow and Ice Data Center Distributed Active Archive Center, Boulder, Colorado, USA, https://doi.org/10.5067/U8C09DWVX9LM, 1999.

Mauritsen, T., Sedlar, J., Tjernström, M., Leck, C., Martin, M., Shupe, M., Sjogren, S., Sierau, B., Persson, P. O. G., Brooks, I. M., and Swietlicki, E.: An Arctic CCN-limited cloud-aerosol regime, Atmos. Chem. Phys., 11, 165-173, https://doi.org/10.5194/acp-11-165-2011, 2011.

McFarquhar, G. M. and Cober, S. G.: Single-scattering properties of mixed-phase Arctic clouds at solar wavelengths: impacts on radiative transfer, J. Climate, 17, 3799-3813, https://doi.org/10.1175/15200442(2004)017<3799:SPOMAC>2.0.CO;2, 2004.

McFarquhar, G. M., Zhang, G., Poellot, M. R., Kok, G. L., McCoy, R., Tooman, T., Fridlind, A., and Heymsfield, A. J.: Ice properties of single-layer stratocumulus during the MixedPhase Arctic Cloud Experiment: 1. Observations, J. Geophys. Res.-Atmos., 112, 1-19, https://doi.org/10.1029/2007JD008633, 2007

Möhler, O., Field, P. R., Connolly, P., Benz, S., Saathoff, H., Schnaiter, M., Wagner, R., Cotton, R., Krämer, M., Mangold, A., and Heymsfield, A. J.: Efficiency of the deposition mode ice nucleation on mineral dust particles, Atmos. Chem. Phys., 6, 30073021, https://doi.org/10.5194/acp-6-3007-2006, 2006.

Möhler, O., DeMott, P. J., Vali, G., and Levin, Z.: Microbiology and atmospheric processes: the role of biological particles in cloud physics, Biogeosciences, 4, 1059-1071, https://doi.org/10.5194/bg-4-1059-2007, 2007.

Morrison, H., Thompson, G., and Tatarskii, V.: Impact of cloud microphysics on the development of trailing stratiform precipitation in a simulated squall line: comparison of one- and two-moment schemes, Mon. Weather Rev., 137, 991-1007, https://doi.org/10.1175/2008MWR2556.1, 2009.

Mossop, S. C.: Production of secondary ice particles during the growth of graupel by riming, Nature, 102, 45-57, https://doi.org/10.1038/249026a0, 1976.

Mossop, S. C.: Secondary ice particle production during rime growth: the effect of drop size distribution and rimer velocity, Q. J. Roy. Meteorol. Soc., 111, 1113-1124, https://doi.org/10.1002/qj.49711147012, 1985.

Mossop, S. C. and Hallett, J.: Ice crystal concentration in cumulus clouds: influence of the drop spectrum, Science, 186, 632-634, https://doi.org/10.1126/science.186.4164.632, 1974.

Murray, B. J., O'Sullivan, D., Atkinson, J. D., and Webb, M. E.: Ice nucleation by particles immersed in supercooled cloud droplets, Chem. Soc. Rev., 41, 6519-54, https://doi.org/10.1039/c2cs35200a, 2012.

Niemand, M., Möhler, O., Vogel, B., Vogel, H., Hoose, C., Connolly, P., Klein, H., Bingemer, H., DeMott, P., Skrotzki, J., and Leisner, T.: A particle-surface-area-based parameterization of immersion freezing on desert dust particles, J. Atmos. Sci., 69, 3077-3092, https://doi.org/10.1175/JAS-D-11-0249.1, 2012.

Palm, S. P., Yang, Y., Spinhirne, J. D., and Marshak, A.: Satellite remote sensing of blowing snow properties over Antarctica, J. Geophys. Res.-Atmos., 116, 1-16, https://doi.org/10.1029/2011JD015828, 2011.

Petters, M. D. and Kreidenweis, S. M.: A single parameter representation of hygroscopic growth and cloud condensation nucleus activity, Atmos. Chem. Phys., 7, 1961-1971, https://doi.org/10.5194/acp-7-1961-2007, 2007.

Pringle, K. J., Tost, H., Pozzer, A., Pöschl, U., and Lelieveld, J.: Global distribution of the effective aerosol hygroscopicity parameter for $\mathrm{CCN}$ activation, Atmos. Chem. Phys., 10, 52415255, https://doi.org/10.5194/acp-10-5241-2010, 2010.

Rangno, A. L. and Hobbs, P. V.: Ice particles in stratiform clouds in the Arctic and possible mechanisms for the production of high ice concentrations, J. Geophys. Res.-Atmos., 106, 15065 , https://doi.org/10.1029/2000JD900286, 2001.

Rosenberg, P. D., Dean, A. R., Williams, P. I., Dorsey, J. R., Minikin, A., Pickering, M. A., and Petzold, A.: Particle sizing calibration with refractive index correction for light scattering optical particle counters and impacts upon PCASP and CDP data collected during the Fennec campaign, Atmos. Meas. Tech., 5, 1147-1163, https://doi.org/10.5194/amt-5-1147-2012, 2012.

Stein, A. F., Draxler, R. R., Rolph, G. D., Stunder, B. J. B., Cohen, M. D., and Ngan, F.: NOAA's HYSPLIT atmospheric transport and dispersion modeling system, B. Am. Meteorol. Soc., 2015, 2059-2077, https://doi.org/10.1175/BAMS-D-14$00110.1,2015$.

Taylor, J. W., Choularton, T. W., Blyth, A. M., Liu, Z., Bower, K. N., Crosier, J., Gallagher, M. W., Williams, P. I., Dorsey, J. R., Flynn, M. J., Bennett, L. J., Huang, Y., French, J., Korolev, A., and Brown, P. R. A.: Observations of cloud microphysics and ice formation during COPE, Atmos. Chem. Phys., 16, 799-826, https://doi.org/10.5194/acp-16-799-2016, 2016.

Thorpe, A. D. and Mason, B. J.: The evaporation of ice spheres and ice crystals, Brit. J. Appl. Phys., 17, 541-548, https://doi.org/10.1088/0508-3443/17/4/316, 1966.

Topping, D. O., McFiggans, G. B., and Coe, H.: A curved multicomponent aerosol hygroscopicity model framework: Part 1 - Inorganic compounds, Atmos. Chem. Phys., 5, 1205-1222, https://doi.org/10.5194/acp-5-1205-2005, 2005.

Vali, G., Leon, D., and Snider, J. R.: Ground-layer snow clouds, Q. J. Roy. Meteorol. Soc., 138, 1507-1525, https://doi.org/10.1002/qj.1882, 2012. 
van den Broeke, M. R., Bamber, J., Lenaerts, J., and Rignot, E.: Ice sheets and sea level: thinking outside the box, Surv. Geophys., 32, 495-505, https://doi.org/10.1007/s10712-011-9137-z, 2011.

Verlinde, J., Harrington, J. Y., McFarquhar, G. M., Yannuzzi, V. T., Avramov, A., Greenberg, S., Johnson, N., Zhang, G., Poellot, M. R., Mather, J. H., Turner, D. D., Eloranta, E. W., Zak, B. D., Prenni, A. J., Daniel, J. S., Kok, G. L., Tobin, D. C., Holz, R., Sassen, K., Spangenberg, D., Minnis, P., Tooman, T. P., Ivey, M. D., Richardson, S. J., Bahrmann, C. P., Shupe, M., DeMott, P. J., Heymsfield, A. J., and Schofield, R.: The mixed-phase arctic cloud experiment, B. Am. Meteorol. Soc., 88, 205-221, https://doi.org/10.1175/BAMS-88-2-205, 2007.

Virkkula, A., Teinilä, K., Hillamo, R., Kerminen, V.-M., Saarikoski, S., Aurela, M., Viidanoja, J., Paatero, J., Koponen, I. K., and Kulmala, M.: Chemical composition of boundary layer aerosol over the Atlantic Ocean and at an Antarctic site, Atmos. Chem. Phys., 6, 3407-3421, https://doi.org/10.5194/acp-6-3407-2006, 2006.

Weller, R., Wöltjen, J., Piel, C., Resenberg, R., Wagenbach, D., König-Langlo, G., and Kriews, M.: Seasonal variability of crustal and marine trace elements in the aerosol at Neumayer station, Antarctica, Tellus B, 60, 742-752, https://doi.org/10.1111/j.1600-0889.2008.00372.x, 2008.

Weller, R., Minikin, A., Wagenbach, D., and Dreiling, V.: Characterization of the inter-annual, seasonal, and diurnal variations of condensation particle concentrations at Neumayer, Antarctica, Atmos. Chem. Phys., 11, 13243-13257, https://doi.org/10.5194/acp-11-13243-2011, 2011.
Whitehead, J. D., Darbyshire, E., Brito, J., Barbosa, H. M. J., Crawford, I., Stern, R., Gallagher, M. W., Kaye, P. H., Allan, J. D., Coe, H., Artaxo, P., and McFiggans, G.: Biogenic cloud nuclei in the central Amazon during the transition from wet to dry season, Atmos. Chem. Phys., 16, 9727-9743, https://doi.org/10.5194/acp-16-9727-2016, 2016.

Wilson, T. W., Ladino, L. A., Alpert, P. A., Breckels, M. N., Brooks, I. M., Browse, J., Burrows, S. M., Carslaw, K. S., Huffman, J. A., Judd, C., Kilthau, W. P., Mason, R. H., McFiggans, G., Miller, L. A., Najera, J., Polishchuk, E., Rae, S., Schiller, C. L., Si, M., Vergara Temprado, J., Whale, T. F., Wong, J. P. S., Wurl, O., Yakobi-Hancock, J. D., Abbatt, J. P. D., Aller, J. Y., Bertram, A. K., Knopf, D. A., and Murray, B. J.: A marine biogenic source of atmospheric ice nucleating particles, Nature, 525, 234-238, https://doi.org/10.1038/nature14986, 2015.

Xu, L., Russell, L. M., Somerville, R. C. J., and Quinn, P. K.: Frost flower aerosol effects on Arctic wintertime longwave cloud radiative forcing, J. Geophys. Res.-Atmos., 118, 13282-13291, https://doi.org/10.1002/2013JD020554, 2013.

Yang, X., Pyle, J. A., and Cox, R. A.: Sea salt aerosol production and bromine release: role of snow on sea ice, Geophys. Res. Lett., 35, 1-5, https://doi.org/10.1029/2008GL034536, 2008.

Yano, J.-I., and Phillips, V. T. J.: Ice-ice collisions: an ice multiplication process in atmospheric clouds, J. Atmos. Sci., 68, 322333, https://doi.org/10.1175/2010JAS3607.1, 2011. 